\title{
A bibliometric analysis of the internationalisation of political science in Europe
}

\section{Marcello Carammia ${ }^{1}$}

Accepted: 27 September 2021 / Published online: 3 March 2022

(c) The Author(s) 2022, corrected publication 2022

\begin{abstract}
Based on data on 67,000 articles published in 100 high-impact journals in the twenty years between 2000 and 2019, I analyse the scientific contribution of European political science scholarly communities in the global context. The scholars contributing to the global scientific production are largely concentrated in a few countries, with the US and UK alone accounting for more than half of the articles published in high-impact journals. However, the tendency is towards increasing diversity in the geographic basis of the international scientific production; and European countries are central to this change. Contributing to international collaborative publications has been a key engine of the increased scientific production of scholars based in Europe. This was a generalised global tendency, and a spectacular one for certain national scholarly communities. The network analysis of international collaborations points to the consolidation of three clusters within a growing and increasingly dense network. The US, followed by the UK, are central to a global cluster of collaborations. European countries are primarily clustered in two groups: a larger and growing cluster; and a smaller but even more integrated, highly productive and connected cluster of scholars based in seven northern European countries. All bibliometric indicators consistently point to a generalised growth in the output and internationalisation of the scientific contribution provided by the European political science community.
\end{abstract}

Keywords Bibliometrics · Europe · Internationalisation · Political science · Publications

Marcello Carammia

marcello.carammia@unict.it

1 Department of Political and Social Sciences, University of Catania, Via Vittorio Emanuele II, 49, 95131 Catania, Italy 


\section{Introduction}

This article uses data on 67,000 articles published in 100 high-impact political science journals in the twenty years between 2000 and 2019 to analyse the publication output of national scholarly communities. Highly regarded journals have a wide readership and international circulation and are commonly referred to as "international journals." Publishing in such journals means contributing to the international scientific scholarship. For these reasons, patterns of publishing in international journals can be analysed as possible indicators of internationalisation (see Tronconi and Engeli in this symposium) — although clearly just one among many (and see also Engeli et al.).

Bibliographic data permit the analysis of publications at the level of journals, articles, authors, academic institutions, and countries. This article focuses on the country level to provide a bibliometric analysis of the internationalisation of European political science against the background of the global scientific production. For each country, or national scholarly community, I use two simple indicators of internationalisation: articles published in the journals selected for this study; and co-authorship of publications, within the same set of journals, with scholars based in different countries. I analyse both indicators in turn and then look more closely into patterns of international authorships through social network analysis.

This approach has some limitations. First, books and book chapters are excluded from this analysis, but they are still highly cited in political science (Jensen and Moses 2021). Second, the journals selected for analysis are not a random sample of journals in the field, but those with the higher five-year impact factor according to the 2020 Journal Citation Report of the Web of Science. The broader community of scholars that publish primarily in other outlets may pursue different paths to internationalisation. Third, the selected journals publish articles in English, and one may argue that this biases the analysis in favour of scholars working in English-speaking countries. Moreover, other internationalised (or regionalised) communities-for example, those publishing in Spanish-would not be captured by this analysis.

These limitations notwithstanding, publications in high-impact academic journals do provide a relevant perspective to the internationalisation of political science. Publishing in highly regarded international journals is central to academic careers and to the measurement of academic performance (Grossman 2020), and it also means contributing to the international scientific debate. Scholarly communities in English-speaking countries are indeed dominant in these journals. But English is the lingua franca of science, so the language bias is probably unavoidable in a study of internationalisation. By focussing on a large sample of leading journals, this study should still "capture the core of the discipline" (Metz and Jäckle 2017, 157)_arguably its most internationalised core.

By mapping a significant part of the international scientific production of a large number of countries over two decades, and describing patterns of international collaboration, this article expands upon the niche of studies using 
bibliometric analysis to assess the status of political science. Political scientists have "a tradition of reflecting on the evolution and state of their discipline" (Fisher et al. 1998, 847). Relevant contributions have focussed on the analysis of subdisciplines, such as public administration (Forrester 1996), international relations (Kristensen 2012), or EU studies (Keeler 2005; Jensen and Kristensen 2013). Gender biases (Williams et al. 2015; Closa et al. 2020; Grossman 2020), single national scholarly communities (e.g. Plümper and Radaelli 2004; Leifeld et al. 2017) or regional groupings such as Central and Eastern Europe (Jokić et al. 2019) also have been the object of some important studies (for a more recent, in-depth discussion of the internationalisation of political science in Central and Eastern Europe, see Kapidžić et al. in this symposium).

Recent bibliometric studies include some contributions to a special symposium in this journal, a focus on influential books and articles (Jensen and Moses 2021), long-term analyses of the articles published in the journals of the European scholarly associations (Ghica 2021), and other articles published in this journal since its launch (Mas-Verdu et al. 2021). Indeed, single journals can provide a relevant perspective on patterns of developments within the discipline, factors of success, and biases; also from the side of editorial work (Closa et al. 2020). Contributions taking a bibliographic network analysis approach (Batagelj and Cerinšek 2013) still represent a small, but growing, share of bibliometric studies in political science (Kristensen 2012; Leifeld et al. 2017; Mas-Verdu et al. 2021; Jensen and Kristensen 2013; Russett and Arnold 2010; Metz and Jäckle 2017).

The article proceeds as follows. The next section presents the dataset. In the findings section, I first provide some descriptive indicators of the contributions of national scholarly communities to the analysed scientific production, and of the involvement in international collaborative publications. I then present a network analysis of international collaborations. In both the descriptive and network analysis sections, I slice the data in two decades-2000-2009 and 2010-2019- to observe the change in patterns of publications and collaborations over time.

\section{Data}

My dataset consists of 67,081 articles published between 2000 and 2019 in 100 journals classified as "political science" in the Social Science Citation Index. ${ }^{1}$ I selected the top-100 journals that in 2019 had a five-year impact factor greater than one (cf. Metz and Jäckle 2017). Table 4 in the Appendix provides the list of selected journals, and the number of articles published in each journal, in the two decades, covered by this article.

The bibliographic record of each article includes a rich set of information, including author details, institutional affiliation, keywords, or journal. The text of each bibliometric record can then be parsed to extract additional information from existing fields. ${ }^{2}$ To

\footnotetext{
1 https://www.webofscience.com/, last accessed 26 November 2021.

2 The complete bibliometric records also include bibliographies, which can be used for mapping, for example, patterns of co-citations or citation couplings among authors or journals.
} 

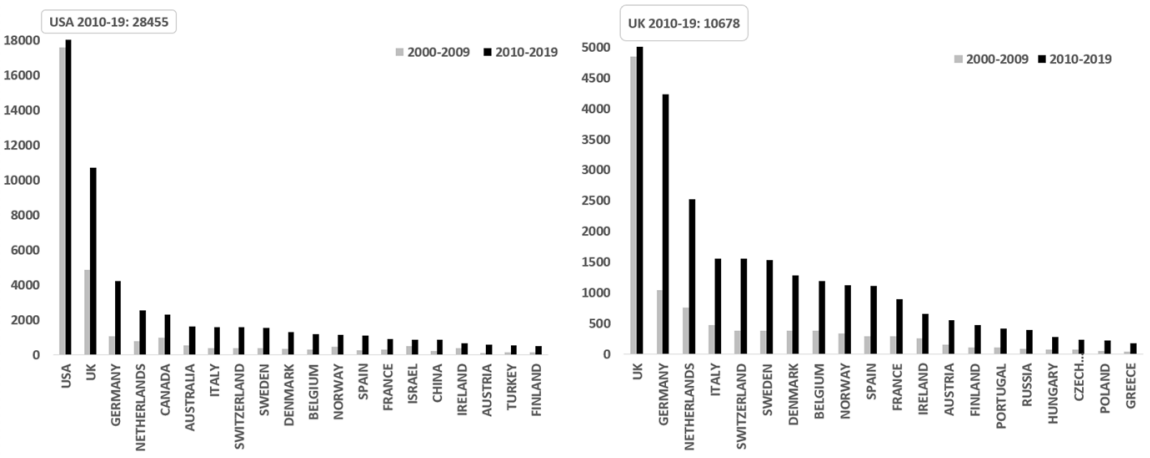

Fig. 1 Contribution to international scientific production. World's top-20 (left quadrant) and European top-20 countries (right quadrant)

parse, process and analyse the large number of bibliometric data downloaded, I used the R package Bibliometrix (Aria and Cuccurullo 2017), which permits leverage of the power and richness of bibliographic data at multiple levels.

To analyse the internationalisation of national scholarly communities, the article focuses on countries as a level of aggregation. This information is extracted from each record by taking the country indicated in the authors' affiliation details. The analysis is centred on European countries, but they are discussed in the context of the broader global political science community: between 2000 and 2019, the political scientists that contributed to the scientific production of the selected journals were based in 127 countries. $^{3}$

\section{Findings}

\section{Contribution to the international scientific production}

Our first indicator of internationalisation of national scholarly communities is the contribution given by scholars, affiliated to institutions based in the respective countries, noting the overall number of articles published by the selected international journals. ${ }^{4}$ For simplicity, and with the caveats discussed above in mind, let us call this a measure of "international scientific production". This is shown in Fig. 1. The left quadrant includes the world's top-20 countries for scientific production, while the European top-20 are shown in the right quadrant. The grey bars display figures

\footnotetext{
3 Replication data and scripts will be made available on the EPS website.

${ }^{4}$ Note that the number of contributions is different from the number of articles. In the case of coauthored articles, the number of contributions for a country is equal to the number of co-authors affiliated to institutions based in that country. For example, one article co-authored by three scholars based in the same country will count as three contributions for that country.
} 
for the decade 2000-2009, while black bars are for 2010-2019. Additional indicators are available in Tables 5 and 6 in the Appendix.

The scientific production of political scientists is highly concentrated in relatively few countries. Indeed in both quadrants, the y-axis is scaled down (truncated) to make the figures for smaller national communities visible; the data for the US and the UK are displayed in a call-out. In the decade 2010-2019, US (41\%) and British $(15 \%)$ institutions together hosted more than half of the (co-)authors of the articles published in the top-100 journals. Just ten countries hosted the authors of $80 \%$ of all articles. European countries were largely represented in this highly productive core: seven among the top-10 for scientific production and fourteen among the top20 were European countries.

Within the general picture of a scientific production concentrated in a relatively small number of countries, however, the data also reveal a tendency towards diversification. In the previous decade (2000-2009), more than $70 \%$ of the scholars who published in the top-100 journals were based in the US or the UK. The top-10 countries hosted $87 \%$, and the top- 20 hosted $95 \%$, of all authors. Over time, the international scientific production became relatively less concentrated across countries. ${ }^{5}$

European countries were key to the increased diversification of international scientific production, in two ways. On the one hand, the European scientific production increased markedly. On the other hand, the contributions to the international scientific production became much more evenly distributed among European countries themselves (see Table 5). To be sure, even in 2010-2019 the UK still provided an affiliation to a large share-roughly one third-of European contributors to publications in the top-100 political science journals; but down from $45 \%$ of Europe's contributions in the previous decade. And while in the second decade, the British contribution more than doubled in absolute numbers (from less than 5000 to more than 10,000), so did the scientific production of the 20 more productive European countries. Meanwhile, contributions by scholars based in Germany, Ireland, Italy, Austria and Hungary more than tripled. ${ }^{6}$

Clearly, UK-based institutions still provide a large share of the European contributions to publications in leading international political science journals. Yet, the

\footnotetext{
5 Table 4 in the Appendix shows some aggregate indicators, all pointing to a broader and more diverse geographic basis of global political science.

${ }^{6}$ Italy and Hungary host two particularly productive academic institutions, the European University Institute and the Central European University, which will likely contribute substantially to the estimated scientific contribution of these countries. It may be debated whether the articles published by scholars affiliated to these institutions should be counted within Hungary and Italy. I decided to leave the data as they are for two main reasons. First, lacking an obvious alternative option, the output of the scholars affiliated to these institutions should be taken out entirely from the dataset, or else be placed on some kind of ad hoc category. This does not sound like a good option. Second and related, other countries also host highly productive institutions which are either private or enjoy special statutes or larger resources. Clearly this is particularly (but not exclusively) the case of the US, where a few big private universities may have a relatively large impact on the country's scientific production. I am not sure that the relationship between these institutions and their host countries is fundamentally different from that of the EUI and CEE and, respectively, Italy and Hungary. Eventually, I decided to leave it to the reader to interpret the findings of this article in the light of this and other possible caveats.
} 


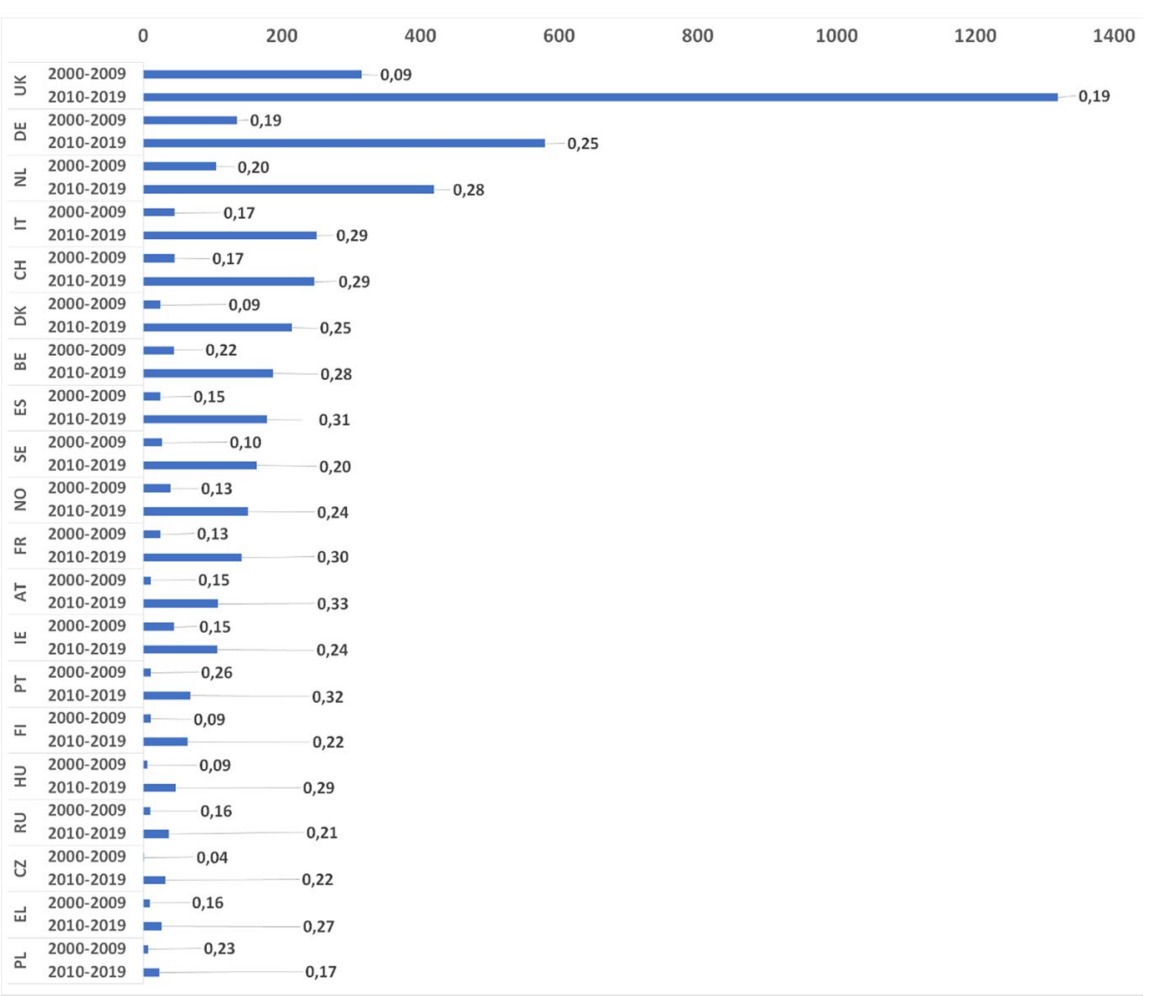

Fig. 2 Involvement in collaborative work by country, European top-20

increase in the amount of contributions from + other European countries has been remarkable.

\section{Participation in international collaborative publications}

Our second indicator of internationalisation of national scholarships is the contribution to collaborative studies co-authored by scholars based in different countries. Multiple country publications (MCP) are shown in Fig. 2, this time only for the 20 European countries with the higher contribution to the international scientific production. For each country, the bars indicate the absolute number of MCP; alongside each bar, the share of MCP on the total number of publications contributed by that country is included. Separate bars for each country show figures for the first and second decades under analysis.

The generalised tendency towards an increased involvement in international collaborative publications outpaced the broader growth of the global scientific production. If we consider the top-35 countries for scientific production (which include the European top-20), single-country publications (SCP) increased by 1.57 (about 
$150 \%$ ) between decades; meanwhile, MCP increased by 5.56 (or about $550 \%$ ) on the average.

This is better appreciated by observing the performance of single countries. In the decade $2000-2009$, MCP represented $20 \%$ or more of the total scientific production in seven European countries: the Netherlands (20\%), Belgium (22\%), Portugal (26\%), Poland (23\%), Romania (25\%), Ukraine (20\%) and Bulgaria (33\%). Except for Belgium and the Netherlands, these were relatively small political science communities producing a limited number of publications. The European average was $17 \%$. In the following decade, MCP grew to $27 \%$ of the total production on the average. They were $20 \%$ or more of the total scientific production in the large majority of European countries, with just eight exceptions. ${ }^{7}$ In relative terms, MCP had increased massively in most European countries. In 2010-2019, they were between four and five times as numerous as in the previous decade in Italy, Switzerland, France and Finland; and between five and eight times more numerous in Denmark, Spain, Sweden, Austria, Portugal and Hungary.

International collaborative publications seem to have been an important component of the general growth of the international scientific production between the two decades. This was a generalised tendency in the large majority of national political science communities. It was certainly so in European countries, where the change was indeed even more marked. These figures complement the description of a growing presence of Europe-based political scientists in the international political science scholarship, with a broader and more diverse geographic basis and a parallel massive increase in collaborative publications. International collaborative research seems to be establishing itself as a key engine for scientific production, in Europe as well as globally. The next section discusses how international collaboration works in practice, and how it has changed along the two decades observed.

\section{Country collaboration network analysis}

Social network analysis permits to look closely into actual patterns of international cooperation. Single countries can be represented as nodes in a network of country collaborations, as in Figs. 3 and 4. Two countries are connected if at least one article was co-authored by scholars working in institutions based in those countries. The higher the number of co-authorships between scholars based in two countries, the stronger the connection between those countries (and the larger the edge joining the related nodes in the network).

Several indicators of connectedness and centrality can be used to obtain a deeper understanding of the network configuration. Table 1 presents some aggregate network-level indicators describing the internal structure of the network and its development over time. Tables 2 and 3 instead provide core 8network statistics at the level

\footnotetext{
7 These were the UK (where the rate was $19 \%$, and the relatively smaller involvement in international publications was clearly the result of a very strong internal capacity, as well as established domestic collaborations), Poland, Romania and Latvia (where it was still around 15\% or more); and Lithuania, Croatia and Albania where international collaborative publications where almost or entirely absent.
} 


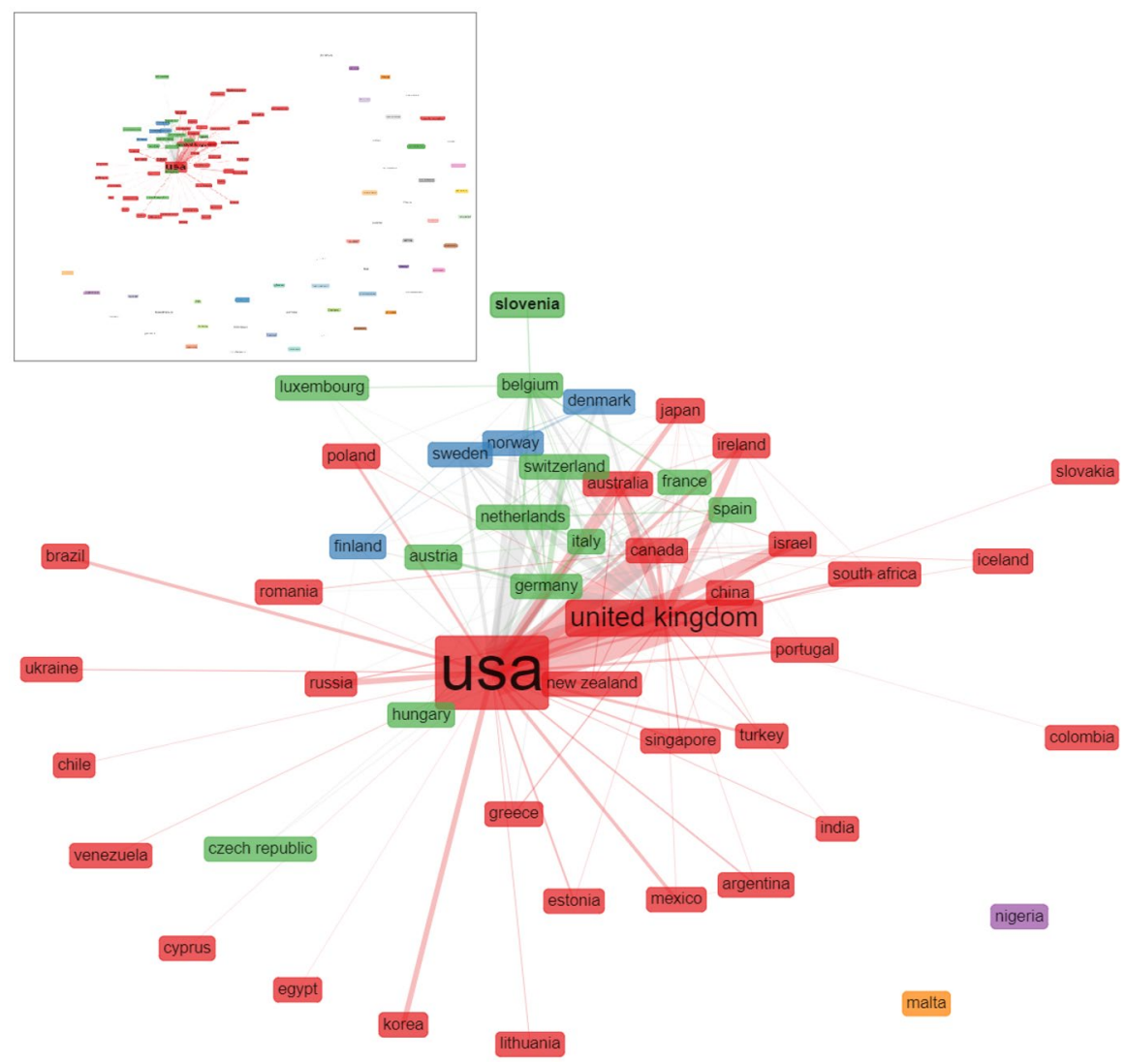

Fig. 3 Country collaboration network, 2000-2009. Entire network in the inset, and fifty most connected countries zoomed in in the chart

of single countries for the 50 nodes with the higher degree (most connections) in the network. Statistics about all countries are shown in Tables 10 and 11 in the Appendix that also include some additional indicators of centrality.

\section{Structure and evolution of the network}

Aggregate network indicators, shown in Table 1 separately for the two decades, consistently point to a broadening and tightening of the network. While it expanded from 106 to 129 countries from the first to the second decade, the network also became twice as densely connected. Despite the larger network size, communication flows (that is, connections between scholars based in different countries) did not become more difficult; the average length of the shortest path connecting two countries actually decreased slightly. 


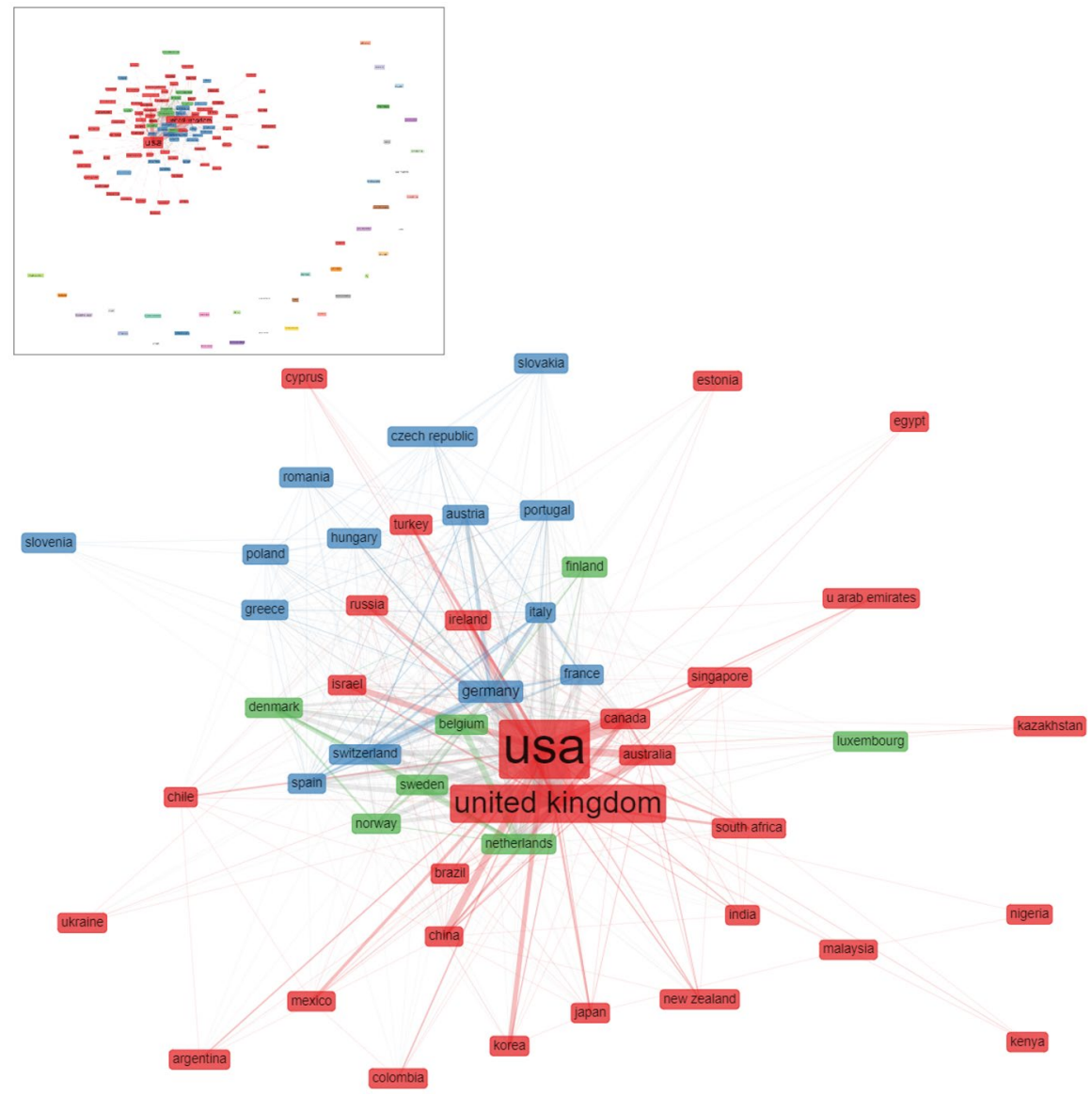

Fig. 4 Country collaboration network, 2010-2019. Entire network in the inset, and fifty most connected countries zoomed in in the chart

Table 1 Network connectedness and development

\begin{tabular}{llllll}
\hline Decade & Nodes & Density & Transitivity & $\begin{array}{l}\text { Degree } \\
\text { centralisa- } \\
\text { tion }\end{array}$ & $\begin{array}{l}\text { Aver- } \\
\text { age path } \\
\text { length }\end{array}$ \\
\hline $2000-2009$ & 106 & 0.0674 & 0.3832 & 0.5993 & 2.1261 \\
$2020-2019$ & 129 & 0.1455 & 0.5452 & 0.6514 & 1.9814 \\
\hline
\end{tabular}

Transitivity measures the extent to which the relations connecting two nodes in the network are "passed on" to other nodes (Wasserman and Faust 1994: 243): how probable is it that if, say, scholars in the US are connected to scholars in Estonia, and scholars in Estonia are connected to scholars in Lithuania, then scholars in Lithuania are also connected to scholars in the US $?^{8}$ This indicator also increased markedly

\footnotetext{
${ }^{8}$ Because it gives an indication of the degree of clustering in the network, transitivity is also known as global clustering coefficient.
} 
Table 2 Country collaboration network. Clustering and centrality of single countries within the network. Fifty most connected countries, 2000-2009

\begin{tabular}{|c|c|c|c|c|c|}
\hline Node & Cluster & Degree & Closeness & Betweenness & Authority \\
\hline USA & 1 & 26,883 & 0.055 & 0.3492 & 1 \\
\hline UK & 1 & 8928 & 0.0544 & 0.1173 & 0.9121 \\
\hline CANADA & 1 & 1869 & 0.054 & 0.093 & 0.7439 \\
\hline AUSTRALIA & 1 & 1082 & 0.0537 & 0.0116 & 0.6658 \\
\hline ISRAEL & 1 & 876 & 0.0534 & 0.0167 & 0.5259 \\
\hline IRELAND & 1 & 785 & 0.0536 & 0.0093 & 0.6127 \\
\hline CHINA & 1 & 423 & 0.0534 & 0.0057 & 0.4183 \\
\hline JAPAN & 1 & 285 & 0.0533 & 0.0003 & 0.3827 \\
\hline NEW ZEALAND & 1 & 278 & 0.0533 & 0.0323 & 0.3109 \\
\hline TURKEY & 1 & 277 & 0.0532 & 0.0022 & 0.3104 \\
\hline RUSSIA & 1 & 265 & 0.0533 & 0.0006 & 0.4392 \\
\hline SOUTH AFRICA & 1 & 229 & 0.0533 & 0.0051 & 0.409 \\
\hline KOREA & 1 & 188 & 0.053 & 0 & 0.2585 \\
\hline SINGAPORE & 1 & 185 & 0.0532 & 0.0049 & 0.3286 \\
\hline MEXICO & 1 & 183 & 0.0531 & 0.0015 & 0.2263 \\
\hline PORTUGAL & 1 & 148 & 0.0531 & 0.0004 & 0.3134 \\
\hline GREECE & 1 & 148 & 0.053 & 0.0004 & 0.2489 \\
\hline BRAZIL & 1 & 141 & 0.053 & 0.0017 & 0.1877 \\
\hline POLAND & 1 & 128 & 0.053 & 0.0004 & 0.2416 \\
\hline ESTONIA & 1 & 88 & 0.0529 & 0 & 0.1629 \\
\hline INDIA & 1 & 69 & 0.0529 & 0.0001 & 0.1364 \\
\hline ARGENTINA & 1 & 69 & 0.0528 & 0 & 0.1105 \\
\hline ICELAND & 1 & 52 & 0.0531 & 0.0001 & 0.2027 \\
\hline SLOVAKIA & 1 & 48 & 0.0531 & 0.0001 & 0.233 \\
\hline CHILE & 1 & 45 & 0.0529 & 0 & 0.1597 \\
\hline ROMANIA & 1 & 42 & 0.0529 & 0 & 0.132 \\
\hline CYPRUS & 1 & 37 & 0.0528 & 0 & 0.1277 \\
\hline EGYPT & 1 & 33 & 0.0528 & 0.0001 & 0.1288 \\
\hline LITHUANIA & 1 & 33 & 0.0526 & 0 & 0.0517 \\
\hline UKRAINE & 1 & 32 & 0.0527 & 0 & 0.0936 \\
\hline VENEZUELA & 1 & 26 & 0.0527 & 0 & 0.0943 \\
\hline GERMANY & 2 & 2093 & 0.054 & 0.0517 & 0.8114 \\
\hline NETHERLANDS & 2 & 1515 & 0.0538 & 0.0079 & 0.7417 \\
\hline ITALY & 2 & 783 & 0.0538 & 0.0098 & 0.7101 \\
\hline SWITZERLAND & 2 & 762 & 0.0536 & 0.003 & 0.6412 \\
\hline BELGIUM & 2 & 631 & 0.0537 & 0.0175 & 0.6446 \\
\hline FRANCE & 2 & 562 & 0.0535 & 0.0191 & 0.5444 \\
\hline SPAIN & 2 & 493 & 0.0536 & 0.0101 & 0.5995 \\
\hline AUSTRIA & 2 & 257 & 0.0532 & 0.0013 & 0.4568 \\
\hline HUNGARY & 2 & 204 & 0.0534 & 0.0017 & 0.4244 \\
\hline CZECH REPUBLIC & 2 & 76 & 0.0529 & 0 & 0.189 \\
\hline
\end{tabular}


Table 2 (continued)

\begin{tabular}{llllll}
\hline Node & Cluster & Degree & Closeness & Betweenness & Authority \\
\hline SLOVENIA & 2 & 63 & 0.0514 & 0.0001 & 0.0361 \\
LUXEMBOURG & 2 & 57 & 0.0528 & 0 & 0.2324 \\
NORWAY & 3 & 871 & 0.0537 & 0.0221 & 0.657 \\
SWEDEN & 3 & 778 & 0.0536 & 0.0036 & 0.5918 \\
DENMARK & 3 & 692 & 0.0534 & 0.002 & 0.4964 \\
FINLAND & 3 & 300 & 0.0532 & 0.0008 & 0.4297 \\
NIGERIA & 4 & 42 & 0.0094 & 0 & 0 \\
MALTA & 5 & 31 & 0.0517 & 0 & 0.0384 \\
\hline
\end{tabular}

from the first to the second decade, which points to the development of more inclusive clusters in the second decade.

Finally, the network became slightly more centralised. Degree centralisation equals one when all nodes connect to a single one, and not to each other (as in a star); it is zero when all nodes are equal (as in a circle). Higher degree centralisation therefore means that there are relatively less very central nodes. This development is consistent with network theory, which sees centralisation as an indicator of network efficiency and posits that while networks grow in size, they will also become more centralised. ${ }^{9}$

What are these best-connected countries? How did the structure of the collaboration network change over time, and what did it mean for the general organisation of international collaborations? To address these questions, we now turn to the descriptive analysis of the network.

\section{0-2009}

Let us begin with the network of international collaboration in the period 2000-2009. For ease of visualisation, Fig. 3 zooms in on the more connected core comprising 50 countries; the entire network is shown in the inset. Nodes (countries) are coloured according to the cluster in which they are placed. ${ }^{10}$ Table 2 complements the graphical visualisation of the network with several centrality indices for single nodes: the cluster to which countries belong; their degree (number of connections); normalised closeness (the steps required to access every other node); betweenness (brokerage potential, measured as the normalised number of shortest paths crossing each node); and authority (connection to nodes that link many other nodes).

In the first decade, the network of 106 countries hosting scholars who published in the political science journals selected for this study included three main clusters, comprising overall 57 countries. The remaining 49 countries were isolated nodes in the network (as can be seen in the inset of Fig. 3). The main cluster (red in the figure) included 41 countries and had the US - the country scoring highest on all network indicators by far-at the centre. We may call this the global cluster. The

\footnotetext{
9 Because of preferential attachment to degree, new nodes will tend to connect to the more connected existing nodes (Barabasi 2014). Preferential attachment to degree creates networks with a power law degree distribution: many nodes with low degree and few nodes with high degree.

${ }^{10}$ I used the Fruchterman \& Reingold clustering algorithm. Add reference/weblink?
} 
Table 3 Country collaboration network. Clustering and centrality of single countries within the network. Fifty most connected countries, 2010-2019

\begin{tabular}{|c|c|c|c|c|c|}
\hline Node & Cluster & Degree & Closeness & Betweenness & Authority \\
\hline USA & 1 & 40,197 & 0.4555 & 0.2835 & 1 \\
\hline UK & 1 & 20,072 & 0.4369 & 0.1655 & 0.9731 \\
\hline CANADA & 1 & 4570 & 0.4 & 0.0644 & 0.8427 \\
\hline AUSTRALIA & 1 & 3357 & 0.3902 & 0.0464 & 0.7811 \\
\hline CHINA & 1 & 1688 & 0.3765 & 0.0056 & 0.7232 \\
\hline ISRAEL & 1 & 1599 & 0.3668 & 0.0036 & 0.6368 \\
\hline IRELAND & 1 & 1526 & 0.3844 & 0.0137 & 0.8078 \\
\hline TURKEY & 1 & 1053 & 0.3678 & 0.0205 & 0.6274 \\
\hline RUSSIA & 1 & 848 & 0.3743 & 0.0043 & 0.7043 \\
\hline KOREA & 1 & 847 & 0.3526 & 0.0004 & 0.4245 \\
\hline SOUTH AFRICA & 1 & 834 & 0.371 & 0.0196 & 0.5559 \\
\hline JAPAN & 1 & 603 & 0.3575 & 0.0025 & 0.452 \\
\hline SINGAPORE & 1 & 554 & 0.3657 & 0.0062 & 0.57 \\
\hline NEW ZEALAND & 1 & 497 & 0.3536 & 0.0019 & 0.437 \\
\hline MEXICO & 1 & 488 & 0.3596 & 0.0015 & 0.5242 \\
\hline BRAZIL & 1 & 483 & 0.3699 & 0.003 & 0.6696 \\
\hline CHILE & 1 & 356 & 0.3606 & 0.002 & 0.5994 \\
\hline INDIA & 1 & 317 & 0.3606 & 0.0093 & 0.4496 \\
\hline ARGENTINA & 1 & 217 & 0.3488 & 0.0004 & 0.4185 \\
\hline COLOMBIA & 1 & 204 & 0.3478 & 0.0011 & 0.3563 \\
\hline U ARAB EMIR & 1 & 186 & 0.3413 & 0.0002 & 0.2667 \\
\hline CYPRUS & 1 & 156 & 0.3596 & 0.0002 & 0.572 \\
\hline ESTONIA & 1 & 154 & 0.345 & 0.0001 & 0.327 \\
\hline EGYPT & 1 & 122 & 0.3316 & 0.0007 & 0.1447 \\
\hline UKRAINE & 1 & 102 & 0.3488 & 0 & 0.4291 \\
\hline KAZAKHSTAN & 1 & 100 & 0.3377 & 0.0011 & 0.1835 \\
\hline KENYA & 1 & 92 & 0.3422 & 0.0006 & 0.2345 \\
\hline GERMANY & 2 & 8193 & 0.4063 & 0.0419 & 0.9251 \\
\hline SWITZERLAND & 2 & 3336 & 0.3855 & 0.0212 & 0.794 \\
\hline ITALY & 2 & 3252 & 0.3926 & 0.0255 & 0.8568 \\
\hline SPAIN & 2 & 2209 & 0.3844 & 0.014 & 0.7779 \\
\hline FRANCE & 2 & 1854 & 0.3938 & 0.0601 & 0.8238 \\
\hline AUSTRIA & 2 & 1351 & 0.3754 & 0.0031 & 0.7588 \\
\hline PORTUGAL & 2 & 775 & 0.3721 & 0.0198 & 0.716 \\
\hline HUNGARY & 2 & 672 & 0.3765 & 0.0031 & 0.7693 \\
\hline CZECH REPUBLIC & 2 & 536 & 0.3743 & 0.0094 & 0.7164 \\
\hline POLAND & 2 & 509 & 0.3787 & 0.0071 & 0.7797 \\
\hline GREECE & 2 & 478 & 0.3754 & 0.003 & 0.7591 \\
\hline ROMANIA & 2 & 230 & 0.3606 & 0.0004 & 0.6023 \\
\hline SLOVAKIA & 2 & 151 & 0.3699 & 0.001 & 0.6988 \\
\hline SLOVENIA & 2 & 107 & 0.3556 & 0.0024 & 0.5161 \\
\hline
\end{tabular}


Table 3 (continued)

\begin{tabular}{llllll}
\hline Node & Cluster & Degree & Closeness & Betweenness & Authority \\
\hline LITHUANIA & 2 & 99 & 0.3636 & 0.0007 & 0.6086 \\
BULGARIA & 2 & 93 & 0.3516 & 0.0001 & 0.4842 \\
NETHERLANDS & 3 & 5196 & 0.4 & 0.0344 & 0.8832 \\
SWEDEN & 3 & 2964 & 0.3844 & 0.008 & 0.8198 \\
DENMARK & 3 & 2916 & 0.381 & 0.0129 & 0.7737 \\
BELGIUM & 3 & 2517 & 0.3821 & 0.0146 & 0.7678 \\
NORWAY & 3 & 2339 & 0.3776 & 0.0138 & 0.724 \\
FINLAND & 3 & 976 & 0.3821 & 0.0096 & 0.7909 \\
LUXEMBOURG & 3 & 145 & 0.3432 & 0 & 0.2905 \\
\hline
\end{tabular}

UK was the second most central actor in this cluster (and in the broader network), alongside of other countries to which it is historically connected, such as Canada, Australia, New Zealand-as well as Ireland in the first place. This cluster has a few more well-connected countries, notably Israel, China, and Japan.

Importantly, 12 European countries were part of this cluster. In addition to Ireland and the UK, these were Cyprus, Estonia, Greece, Iceland, Latvia, Lithuania, Poland, Portugal, Romania, Russia, Slovakia and Ukraine. Of these, Greece, Portugal and to some extent Estonia had a relatively high degree compared to other countries within the cluster, but limited network centrality and virtually no brokering potential. The other European countries were part of this collaboration cluster primarily because scholars based there had collaborated with colleagues from the main hubs within the cluster.

Most remaining countries within the global cluster were weakly connected in all respects. These included the larger Latin American countries (Argentina, Brazil, Colombia, Chile, Mexico, Venezuela), as well as several African (Burkina Faso, Egypt, Ethiopia, South Africa, Zimbabwe,), Asian (India, Indonesia, Korea, Kyrgyzstan, Philippines, Singapore, Sri Lanka) and Pacific (Fiji) countries. Such countries had a low degree (number of connections) and no brokering capacity; in general, they scored poorly on all connection indices. Overall, they were peripheral to the global cluster and were part of it because of their collaborations with few countries from its core.

Most European countries were part of the two remaining clusters. One larger European cluster included 12 nodes, with Germany and the Netherlands at the centre. They clearly had a key brokering role within the European cluster, being pivotal to collaborations among scholars from many other European countries; but their degree and centrality scores made them actually quite central to the entire network. To a relatively smaller extent, this was also the case for Italy and Switzerland, and less so for Spain and France.

Belgium was a somehow special country within the European cluster. Its betweenness was extremely high compared to its degree (still relatively high compared to the size of the country). Although limited in mass, scholars based in Belgium were able to place themselves at the centre of a tight web of international collaborations, particularly with other European colleagues. Austria and Hungary were 
the remaining European countries with a marked degree and some betweenness in the network. The Czech Republic, Slovenia and Luxembourg had some degree but no brokering capacity.

The second cluster of European countries was composed of the Scandinavian countries: Denmark, Finland, Norway and Sweden. Their relatively high degree, as well as the web of collaboration within and outside the cluster, is what placed these countries in a cluster of their own. Among them, Norway, Sweden and Denmark had the higher degree (comparable to such countries as Italy or Switzerland in the main European cluster, or Ireland and Israel in the global cluster) and also a significant centrality. Sweden was second by degree, but it was by far the main hub, both within the cluster and with other countries.

Finally, the network included a set of 49 individual nodes with no systematic relations with any cluster of countries. Scholars based in these countries either did not publish collaborative work with colleagues based in other countries, or (in a smaller number of instances) their collaborations happened mainly or exclusively with single countries. In short, they were not systematically connected to international networks of collaboration for articles published in the top-100 international journals. This set of countries, that constituted about half of the entire network, included eight European countries: Malta, Bulgaria, Serbia, Croatia, Belarus, Moldova, Monaco and Montenegro (in decreasing order of network degree). None of them had any significant centrality or brokering capacity within the overall network.

\section{0-2019}

Figure 4 displays the network of country collaborations in the decade 2010-2019. Again, the figure zooms in on the top-50 countries for degree within the network, while the entire network is shown in the inset; single countries are coloured based on the subgroup to which they belong. Indicators of centrality and connectedness of single countries are shown in Table 3 for the 50 most connected countries within the network. Table 8in the Appendix provides centrality indicators for all countries in the network.

By 2010-2019, the network had expanded in size, but the isolated nodes had decreased both in relative and absolute terms: less than one third of the countries-37 out of 129 countries-were now excluded from collaboration clusters, compared to almost half of the 106 countries composing the network in the previous decade. International collaborations were still organised around three clusters of scholarly communities, and these groupings maintained their overall identity: one global cluster and two (mainly) European clusters. However, all expanded in size and deepened in terms of interactions.

The global cluster expanded to include 62 nodes. The US and UK maintained their centrality within the cluster (as well as within the broader network): their score 
on degree and centrality measures actually increased markedly in the second decade. Canada and Australia followed, also part of the top-10 most connected, central, and in-between countries in the broader network. More countries within the global cluster became tightly connected (see Table 3). Canada, Australia, Israel, China, Ireland and Turkey all had a degree (number of international co-authorships) higher than 1000; Russia, South Africa, Korea, Japan, Singapore, Brazil, Mexico and New Zealand higher than 500 .

Although significantly lower in network degree, Ireland and Turkey stood out for their high centrality score and brokering capacity within the network (as shown by the betweenness and hub indicators). The latter in particular was rather well connected to many countries in the European cluster, as was the case for some Latin American countries, such as Brazil and Chile. Korea, Japan and Singapore also were quite well connected within the global cluster; less so with countries in the European cluster.

The global cluster included ten European countries (down from fourteen in the previous decade), four of which were European Union members. In addition to the UK and Ireland, European countries in the global cluster were Russia, Cyprus, Estonia, Ukraine, Serbia, Iceland, Croatia, and Belarus. Russian scholars stood out for the scope of their connections with Europe, having co-published with scholars from 18 (other) European countries - a massive increase from the previous decade, when Russian scholars only published collaborative work with scholars from the UK, Germany and Finland. With the partial exception of Cyprus and Estonia, the remaining European countries within the global cluster had limited connections within, and poor or no connection outside of it.

By 2010-2019, most of the scholars from European countries had tightened their collaboration with European colleagues. As a result, the larger European cluster grew to include 20 nodes; up from 12 in the previous decade, and now also comprising three non-European countries (Qatar, Jordan and Venezuela). The top-three countries for connection, authority and centrality within the main European cluster-Germany, Switzerland and Italy - were also among the top-10 most connected countries of the broader network of international collaborations. France was among the top-10 for most centrality indicators, although not for degree. In general, most countries within the European cluster were well connected within and outside of it; relatively less so were scholars in Slovenia, Lithuania and Bulgaria, as well as the three non-European countries.

The second European cluster also grew in size, from four to nine nodes. The four Scandinavian countries were joined by Belgium, Luxembourg, and the Netherlands - another well-connected and internationalised community of scholars-as well as Malta and Mozambique. While no longer a Scandinavian cluster, this was still a Northern European one. Malta was part of it because of some repeated collaborations between a few productive scholars with colleagues in the Netherlands, 
and Mozambique because of co-authored publications with scholars in Norway and Denmark. ${ }^{11}$

The Northern European cluster was tightly connected internally as well as externally. Scholars based in the countries that were part of this cluster used to collaborate systematically with colleagues from other countries of the same group. However, this was also a highly internationalised cluster-and a very successful one in terms of scientific production. Three countries - the Netherlands, Sweden, and Denmark-ranked among the world's top-10 for degree and on most other indicators of centrality and authority. Belgium and Norway followed shortly after.

The Netherlands can be considered an exceptionally successful case. Despite its small size, it ranked fourth globally on most indicators; after the US, the UK and Germany but before Italy, Canada, Australia, or France. Although to a slightly smaller degree, Switzerland, Sweden, Denmark, Belgium and Norway are comparable cases of relatively small but extremely productive and internationalised political science communities. All of them, except Switzerland, were part of the Northern European cluster.

\section{Conclusions}

Based on an original dataset of more than 67,000 articles published in high-impact political science journals between 2000 and 2019, this article has provided a bibliometric analysis of the internationalisation of European political science against the broader context of the global scholarship.

The contribution to the international scientific production, as defined for the purposes of this article, is highly concentrated in relatively few countries. In the decade 2010-2019, scholars based in the US contributed more than 40\%, and British scholars $15 \%$, of the total production. However, their combined share of the total production was much smaller than in the previous decade. This was to a large extent a consequence of the growth in the output of European political science communities.

The scientific production grew massively between decades, and it became relatively more evenly distributed among countries. This was especially the case in Europe. In 2010-2019, the UK contributed by about one third to the European scientific production; still a large share, but down from $45 \%$ in the previous decade. The publication output more than doubled in all but one of the top-20 European countries, and tripled in five of them.

International collaborative research-in the form of co-authorships between scholars based in different countries-is establishing itself as a key engine of scientific production. This is a generalised global trend, and a sustained one in Europe where publications co-authored by scholars based in different countries accounted for more than one fourth of the entire output. They were between four and five times as numerous in 2010-2019 as in the previous decade in Italy,

\footnotetext{
11 These countries had a rather limited presence in the top-100 political science journals, so structured collaborations by one or two productive scholars could effectively determine the positioning of the country in one or the other cluster, which seems to be what happened in these cases.
} 
Switzerland, France and Finland; and between five and eight times more in Denmark, Spain, Sweden, Austria, Portugal and Hungary.

Over the past two decades, the global political science scholarship has multiplied its output, broadened its geographic basis, and tightened international collaborations. European political scientists have been central to this development. This is nicely illustrated by the analysis of the international network of country collaborations, which became larger, denser, better connected, and more centralised over time. Three clusters of closer country collaborations were already present in the first observed decade. They all consolidated and increased in size in the second decade. Meanwhile, isolated countries in the network - that is, national scholarly communities publishing in high-ranking journals but with limited or no collaboration with scholars from other countries-went down from almost half to less than one third of the network.

The US and the UK are still central to the global cluster, which comprises almost half of the entire network. European political scientists cluster around two sub-communities: a larger group of scholars based in seventeen countries; and an even more integrated, highly productive and connected core of scholars based in seven Northern European countries.

Against the context of a massively growing scholarly production, and a tightening network of international collaborations, some European countries had an exceptional performance. But all bibliometric indicators consistently point to a generalised growth in the output and internationalisation of the scientific contribution of the European political science community.

\section{Appendix}

\section{A bibliometric analysis of the internationalisation of political science in Europe}

\section{Sources}

See Table 4 
Table 4 List of journals included in the analysis, and number of articles by journal in the first and second decade

\begin{tabular}{|c|c|c|}
\hline Journal & 2010-19 & $2000-09$ \\
\hline PUBLIC CHOICE & 994 & 898 \\
\hline PS-POLITICAL SCIENCE \& POLITICS & 957 & 802 \\
\hline JOURNAL OF POLITICS & 954 & 625 \\
\hline SOCIAL SCIENCE QUARTERLY & 925 & 717 \\
\hline ELECTORAL STUDIES & 883 & 430 \\
\hline JCMS-JOURNAL OF COMMON MARKET STUDIES & 882 & 240 \\
\hline JOURNAL OF EUROPEAN PUBLIC POLICY & 867 & 547 \\
\hline ANNALS OF THE AMER ACAD OF POL AND SOC SCIENCE & 753 & 712 \\
\hline GLOBAL POLICY & 711 & - \\
\hline POLITICAL QUARTERLY & 707 & 491 \\
\hline EUROPE-ASIA STUDIES & 697 & 516 \\
\hline POLITICAL RESEARCH QUARTERLY & 692 & 486 \\
\hline WEST EUROPEAN POLITICS & 686 & 461 \\
\hline AMERICAN JOURNAL OF POLITICAL SCIENCE & 685 & 573 \\
\hline EUROPEAN JOURNAL OF POLITICAL ECONOMY & 652 & 99 \\
\hline INTERNATIONAL STUDIES QUARTERLY & 637 & 305 \\
\hline POLITICAL STUDIES & 623 & 392 \\
\hline PUBLIC ADMINISTRATION & 608 & 423 \\
\hline JOURNAL OF CONFLICT RESOLUTION & 607 & 372 \\
\hline DEMOCRATIZATION & 604 & 96 \\
\hline COMPARATIVE POLITICAL STUDIES & 602 & 437 \\
\hline PARTY POLITICS & 597 & 314 \\
\hline SURVIVAL & 584 & 395 \\
\hline POLITICAL PSYCHOLOGY & 580 & 339 \\
\hline CITIZENSHIP STUDIES & 569 & 33 \\
\hline JOURNAL OF PEACE RESEARCH & 556 & 362 \\
\hline POLITICAL GEOGRAPHY & 544 & 355 \\
\hline ENVIRONMENTAL POLITICS & 531 & 283 \\
\hline JOURNAL OF DEMOCRACY & 529 & 540 \\
\hline EUROPEAN JOURNAL OF POLITICAL RESEARCH & 506 & 602 \\
\hline AMERICAN POLITICAL SCIENCE REVIEW & 498 & 412 \\
\hline TERRORISM AND POLITICAL VIOLENCE & 485 & 277 \\
\hline PARLIAMENTARY AFFAIRS & 477 & 425 \\
\hline NATIONS AND NATIONALISM & 464 & 55 \\
\hline LOCAL GOVERNMENT STUDIES & 463 & 298 \\
\hline BRITISH JOURNAL OF POLITICAL SCIENCE & 446 & 326 \\
\hline REVIEW OF AFRICAN POLITICAL ECONOMY & 442 & 45 \\
\hline GEOPOLITICS & 436 & 88 \\
\hline REVIEW OF INTERNATIONAL POLITICAL ECONOMY & 436 & 274 \\
\hline JOURNAL OF PUBL ADMIN RES AND THEORY & 430 & 236 \\
\hline AMERICAN POLITICS RESEARCH & 421 & 297 \\
\hline
\end{tabular}


Table 4 (continued)

\begin{tabular}{|c|c|c|}
\hline Journal & $2010-19$ & $2000-09$ \\
\hline PUBLIC OPINION QUARTERLY & 417 & 323 \\
\hline JOURNAL OF EUROPEAN INTEGRATION & 416 & - \\
\hline NEW POLITICAL ECONOMY & 401 & 161 \\
\hline BRIT JOURNAL OF POLITICS \& INTERNAT RELAT & 392 & 77 \\
\hline INTERNATIONAL POLITICAL SCIENCE REVIEW & 381 & 198 \\
\hline POLITICAL BEHAVIOR & 378 & 179 \\
\hline JOURNAL OF STRATEGIC STUDIES & 374 & 288 \\
\hline ARMED FORCES \& SOCIETY & 370 & 261 \\
\hline COMPARATIVE EUROPEAN POLITICS & 366 & 38 \\
\hline CAMBRIDGE REVIEW OF INTERNATIONAL AFFAIRS & 362 & 58 \\
\hline SOCIAL MOVEMENT STUDIES & 352 & - \\
\hline POLICY STUDIES JOURNAL & 347 & 383 \\
\hline POLICY AND POLITICS & 337 & 309 \\
\hline COMMUNIST AND POST-COMMUNIST STUDIES & 332 & 251 \\
\hline NEW LEFT REVIEW & 328 & 341 \\
\hline GOVERNANCE-INT J OF POLICY ADMIN AND INSTITS & 327 & 125 \\
\hline EUROPEAN POLITICAL SCIENCE & 326 & 63 \\
\hline HUMAN RIGHTS QUARTERLY & 319 & 298 \\
\hline EUROPEAN UNION POLITICS & 306 & 155 \\
\hline POLITICAL ANALYSIS & 303 & 161 \\
\hline PROBLEMS OF POST-COMMUNISM & 302 & 296 \\
\hline POLITICS & 299 & 51 \\
\hline SOCIO-ECONOMIC REVIEW & 299 & 21 \\
\hline CONTEMPORARY POLITICS & 298 & - \\
\hline PERSPECTIVES ON POLITICS & 298 & 72 \\
\hline INTERN JOURNAL OF PUBL OP RES & 296 & 244 \\
\hline INTERN ENVIRONM AGREEMNTS-POL LAW AND EC & 294 & 38 \\
\hline AFRICAN AFFAIRS & 288 & 226 \\
\hline JOURNAL OF HUMAN RIGHTS & 287 & 44 \\
\hline POLITICAL COMMUNICATION & 286 & 225 \\
\hline REGULATION \& GOVERNANCE & 281 & 59 \\
\hline INTERNATIONAL ORGANIZATION & 278 & 241 \\
\hline SOUTH EUROPEAN SOCIETY AND POLITICS & 272 & 75 \\
\hline PUBLIUS-THE JOURNAL OF FEDERALISM & 271 & 261 \\
\hline JOURNAL OF INTERN RELAT AND DEVELOPM & 268 & 47 \\
\hline POLITICAL THEORY & 264 & 245 \\
\hline GLOBAL ENVIRONMENTAL POLITICS & 260 & 90 \\
\hline MEDITERRANEAN POLITICS & 257 & 46 \\
\hline POLITICAL STUDIES REVIEW & 257 & 26 \\
\hline INTERNATIONAL JOURNAL OF PRESS-POLITICS & 254 & 40 \\
\hline COOPERATION AND CONFLICT & 253 & 71 \\
\hline COMPARATIVE POLITICS & 248 & 202 \\
\hline
\end{tabular}


Table 4 (continued)

\begin{tabular}{lll}
\hline Journal & $2010-19$ & $2000-09$ \\
\hline INTERNATIONAL STUDIES REVIEW & 247 & 49 \\
GOVERNMENT AND OPPOSITION & 245 & 224 \\
INTERN J OF TRANSITIONAL JUSTICE & 243 & 65 \\
LATIN AMERICAN POLITICS AND SOCIETY & 242 & 170 \\
JOURNAL OF POLITICAL PHILOSOPHY & 241 & 229 \\
POLITICS \& GENDER & 241 & 70 \\
ACTA POLITICA & 236 & 98 \\
LEGISLATIVE STUDIES QUARTERLY & 236 & 240 \\
SWISS POLITICAL SCIENCE REVIEW & 235 & 103 \\
ANNUAL REVIEW OF POLITICAL SCIENCE & 222 & 134 \\
STATE POLITICS \& POLICY QUARTERLY & 221 & 97 \\
POST-SOVIET AFFAIRS & 209 & 136 \\
POLITICAL SCIENCE QUARTERLY & 202 & 192 \\
STUDIES IN COMPARAT INTERNAT DEVELOPMENT & 202 & 164 \\
POLITICS \& SOCIETY & 200 & 171 \\
SCANDINAVIAN POLITICAL STUDIES & 185 & 180 \\
WORLD POLITICS & 185 & 136 \\
\hline
\end{tabular}

\section{Contribution to the international scientific production}

See Tables 5 and 6

The Shannon index has been developed in information theory and is used across disciplines (including in political science, Boydstun et al. 2014) to measure diversity in distributions. Shannon's index is normalised in Table 4 so that it would take the value of one in case of equal distribution (that is, if authors were spread in equal number across countries), while a value of zero would indicate full concentration (if all authors were based in a single country). As can be seen, Shannon is markedly higher in the second than in the first decade; and this is even more the case when we look at scientific production in the European subset of countries. 
Table 5 Global scientific production, top-20 countries

\begin{tabular}{|c|c|c|c|c|c|}
\hline \multicolumn{3}{|l|}{ 2010-2019 } & \multicolumn{3}{|l|}{ 2000-2009 } \\
\hline Country & $n$ & Share & Country & $n$ & Share \\
\hline USA & 28,455 & 0.41 & USA & 17,577 & 0.55 \\
\hline UNITED KINGDOM & 10,678 & 0.15 & UNITED KINGDOM & 4850 & 0.15 \\
\hline GERMANY & 4231 & 0.06 & GERMANY & 1042 & 0.03 \\
\hline NETHERLANDS & 2522 & 0.04 & NETHERLANDS & 763 & 0.02 \\
\hline CANADA & 2284 & 0.03 & CANADA & 955 & 0.03 \\
\hline AUSTRALIA & 1622 & 0.02 & AUSTRALIA & 533 & 0.02 \\
\hline ITALY & 1559 & 0.02 & ITALY & 383 & 0.01 \\
\hline SWITZERLAND & 1559 & 0.02 & SWITZERLAND & 381 & 0.01 \\
\hline SWEDEN & 1535 & 0.02 & SWEDEN & 379 & 0.01 \\
\hline DENMARK & 1279 & 0.02 & DENMARK & 343 & 0.01 \\
\hline BELGIUM & 1193 & 0.02 & BELGIUM & 298 & 0.01 \\
\hline NORWAY & 1122 & 0.02 & NORWAY & 474 & 0.01 \\
\hline SPAIN & 1113 & 0.02 & SPAIN & 256 & 0.01 \\
\hline FRANCE & 896 & 0.01 & FRANCE & 298 & 0.01 \\
\hline ISRAEL & 870 & 0.01 & ISRAEL & 475 & 0.01 \\
\hline CHINA & 846 & 0.01 & CHINA & 204 & 0.01 \\
\hline IRELAND & 662 & 0.01 & IRELAND & 387 & 0.01 \\
\hline AUSTRIA & 558 & 0.01 & AUSTRIA & 114 & 0.00 \\
\hline TURKEY & 517 & 0.01 & TURKEY & 142 & 0.00 \\
\hline FINLAND & 477 & 0.01 & FINLAND & 154 & 0.00 \\
\hline
\end{tabular}


Table 6 European scientific production, top-20 countries

\begin{tabular}{|c|c|c|c|c|c|}
\hline \multicolumn{3}{|l|}{ 2010-2019 eur } & \multicolumn{3}{|l|}{ 2000-2009 eur } \\
\hline Country & $n$ & Share & Country & $n$ & Share \\
\hline UNITED KINGDOM & 10,678 & 0.34 & UNITED KINGDOM & 4850 & 0.45 \\
\hline GERMANY & 4231 & 0.13 & GERMANY & 1042 & 0.10 \\
\hline NETHERLANDS & 2522 & 0.08 & NETHERLANDS & 763 & 0.07 \\
\hline ITALY & 1559 & 0.05 & NORWAY & 474 & 0.04 \\
\hline SWITZERLAND & 1559 & 0.05 & IRELAND & 387 & 0.04 \\
\hline SWEDEN & 1535 & 0.05 & ITALY & 383 & 0.04 \\
\hline DENMARK & 1279 & 0.04 & SWITZERLAND & 381 & 0.04 \\
\hline BELGIUM & 1193 & 0.04 & SWEDEN & 379 & 0.04 \\
\hline NORWAY & 1122 & 0.04 & DENMARK & 343 & 0.03 \\
\hline SPAIN & 1113 & 0.04 & BELGIUM & 298 & 0.03 \\
\hline FRANCE & 896 & 0.03 & FRANCE & 298 & 0.03 \\
\hline IRELAND & 662 & 0.02 & SPAIN & 256 & 0.02 \\
\hline AUSTRIA & 558 & 0.02 & FINLAND & 154 & 0.01 \\
\hline FINLAND & 477 & 0.02 & AUSTRIA & 114 & 0.01 \\
\hline PORTUGAL & 417 & 0.01 & RUSSIA & 111 & 0.01 \\
\hline RUSSIA & 398 & 0.01 & HUNGARY & 91 & 0.01 \\
\hline HUNGARY & 285 & 0.01 & GREECE & 77 & 0.01 \\
\hline CZECH REPUBLIC & 231 & 0.01 & PORTUGAL & 73 & 0.01 \\
\hline POLAND & 222 & 0.01 & POLAND & 58 & 0.01 \\
\hline GREECE & 174 & 0.01 & CZECH REPUBLIC & 38 & 0.00 \\
\hline
\end{tabular}

\section{See Tables 7 and 8}

Table 7 Indicators of concentration of the international scientific production in the two decades

Table 8 International publications. Average country collaborations indices and change

\begin{tabular}{lll}
\hline & $2000-2009$ & $2010-2019$ \\
\hline Number of countries-all & 106 & 129 \\
Number of countries-European & 38 & 40 \\
Shannon index-all countries & 0.42 & 0.51 \\
Shannon index-European countries & 0.50 & 0.67 \\
\hline
\end{tabular}

\begin{tabular}{llll}
\hline & $2010-2019$ & $2000-2009$ & Growth \\
\hline All & 0.25 & 0.19 & 5.26 \\
Europe & 0.20 & 0.25 & 5.19 \\
All top-10 & 0.15 & 0.26 & 4.10 \\
European top-10 & 1.60 & 0.26 & 5.65 \\
\hline
\end{tabular}




\section{Participation in international collaborative publications}

Comparing MCP publications among countries is not straightforward. On the one hand, big scholarly communities tend to be integrated in the international community; the scholars based there may have more resources and opportunities to collaborate internationally. On the other hand, relatively smaller and/or less internationally productive scientific communities have stronger incentives to pursue international collaborations, also in order to get access to more opportunities and resources. For several small scholarly communities, MCP represents most or all of their entire scholarly production.

For the same reasons, comparing MCP between European and non-European countries should be done with caution. Several European countries tend to be large contributors to the international scientific production. Therefore, national political science communities in Europe are on the average much larger than scholarly communities in non-European countries, which may bias the comparison. The difference between European and non-European averages should be read against this background. Although rather high in absolute numbers and as a proportion of total publications, in 2010-2019, the average share of MCP was smaller in European countries than in the rest of the world-but it had increased massively from the previous decade. The extent and increase of MCP in Europe can be better appreciated if we compare the top-10 European and the top-10 non-European countries, as in Table 5.

See Table 9 
Table 9 Single-country publications (SCP) and multiple country publications (MCP), top-35 countries, 2010-2019

\begin{tabular}{|c|c|c|c|c|c|c|c|}
\hline Country & SCP & $\mathrm{MCP}$ & Tot & MCP/Tot & SCP change & MCP change & Tot change \\
\hline USA & 14,655 & 1770 & 16,425 & 0.11 & 0.25 & 1.71 & 0.33 \\
\hline UK & 5598 & 1319 & 6917 & 0.19 & 0.66 & 3.19 & 0.88 \\
\hline GERMANY & 1763 & 579 & 2342 & 0.25 & 1.97 & 3.29 & 2.22 \\
\hline NETHRLNDS & 1058 & 419 & 1477 & 0.28 & 1.56 & 2.99 & 1.85 \\
\hline CANADA & 1063 & 342 & 1405 & 0.24 & 0.85 & 2.08 & 1.05 \\
\hline AUSTRALIA & 745 & 256 & 1001 & 0.26 & 1.37 & 2.88 & 1.63 \\
\hline ITALY & 615 & 250 & 865 & 0.29 & 1.86 & 4.56 & 2.33 \\
\hline SWITZERL & 612 & 247 & 859 & 0.29 & 1.81 & 4.49 & 2.27 \\
\hline DENMARK & 636 & 214 & 850 & 0.25 & 1.63 & 7.56 & 2.18 \\
\hline SWEDEN & 675 & 164 & 839 & 0.20 & 1.67 & 5.07 & 2.00 \\
\hline BELGIUM & 482 & 187 & 669 & 0.28 & 2.13 & 3.25 & 2.38 \\
\hline NORWAY & 469 & 151 & 620 & 0.24 & 0.81 & 2.87 & 1.08 \\
\hline SPAIN & 394 & 178 & 572 & 0.31 & 1.83 & 6.12 & 2.49 \\
\hline CHINA & 379 & 136 & 515 & 0.26 & 2.95 & 3.86 & 3.15 \\
\hline ISRAEL & 386 & 123 & 509 & 0.24 & 0.42 & 1.37 & 0.58 \\
\hline FRANCE & 325 & 142 & 467 & 0.30 & 0.91 & 4.68 & 1.39 \\
\hline IRELAND & 337 & 107 & 444 & 0.24 & 0.31 & 1.43 & 0.48 \\
\hline TURKEY & 269 & 62 & 331 & 0.19 & 1.72 & 9.33 & 2.15 \\
\hline AUSTRIA & 216 & 108 & 324 & 0.33 & 2.38 & 8.82 & 3.32 \\
\hline FINLAND & 227 & 64 & 291 & 0.22 & 1.08 & 4.82 & 1.43 \\
\hline KOREA & 186 & 68 & 254 & 0.27 & 3.77 & 6.56 & 4.29 \\
\hline PORTUGAL & 143 & 68 & 211 & 0.32 & 3.61 & 5.18 & 4.02 \\
\hline SOUTH AFR & 158 & 42 & 200 & 0.21 & 1.55 & 5.00 & 1.90 \\
\hline RUSSIA & 137 & 37 & 174 & 0.21 & 1.54 & 2.70 & 1.72 \\
\hline HUNGARY & 115 & 47 & 162 & 0.29 & 0.92 & 6.83 & 1.45 \\
\hline CZECH REP & 112 & 32 & 144 & 0.22 & 3.15 & 31.00 & 4.14 \\
\hline SINGAPORE & 113 & 31 & 144 & 0.22 & 1.05 & 2.44 & 1.25 \\
\hline JAPAN & 112 & 27 & 139 & 0.19 & 0.38 & 2.38 & 0.56 \\
\hline POLAND & 114 & 23 & 137 & 0.17 & 3.75 & 2.29 & 3.42 \\
\hline NEW ZEAL & 87 & 44 & 131 & 0.34 & 0.24 & 1.93 & 0.54 \\
\hline MEXICO & 81 & 32 & 113 & 0.28 & 0.56 & 5.40 & 0.98 \\
\hline BRAZIL & 77 & 29 & 106 & 0.27 & 1.26 & 2.22 & 1.47 \\
\hline GREECE & 71 & 26 & 97 & 0.27 & 0.45 & 1.89 & 0.67 \\
\hline CHILE & 56 & 30 & 86 & 0.35 & 3.00 & 29.00 & 4.73 \\
\hline INDIA & 52 & 19 & 71 & 0.27 & 1.48 & 5.33 & 1.96 \\
\hline
\end{tabular}

Countries are ranked by Tot $(\mathrm{SCP}+\mathrm{MPC})$ number of publications

MCP/Tot: share of multiple country publications on total publications

SCP change: relative increment of single-country publications from previous decade

MCP change: relative increment of multiple country publications from previous decade

Tot change: increment of publications from previous decade 


\section{Country collaboration network. Clustering and centrality Indices}

See Tables 10 and 11

Table 10 Country collaboration network. Clustering and centrality of single countries within the network. All countries, 2000-2009

\begin{tabular}{|c|c|c|c|c|c|c|c|}
\hline Node & Cluster & Degree & Norm degree & Closeness & Betweenness & PageRank & Authority \\
\hline USA & 1 & 26,883 & 0.6667 & 0.0550 & 0.3492 & 0.0979 & 1.0000 \\
\hline UK & 1 & 8928 & 0.4667 & 0.0544 & 0.1173 & 0.0585 & 0.9121 \\
\hline CANADA & 1 & 1869 & 0.3238 & 0.0540 & 0.0930 & 0.0437 & 0.7439 \\
\hline AUSTRALIA & 1 & 1082 & 0.2286 & 0.0537 & 0.0116 & 0.0262 & 0.6658 \\
\hline ISRAEL & 1 & 876 & 0.1619 & 0.0534 & 0.0167 & 0.0196 & 0.5259 \\
\hline IRELAND & 1 & 785 & 0.2095 & 0.0536 & 0.0093 & 0.0248 & 0.6127 \\
\hline CHINA & 1 & 423 & 0.1524 & 0.0534 & 0.0057 & 0.0185 & 0.4183 \\
\hline JAPAN & 1 & 285 & 0.1048 & 0.0533 & 0.0003 & 0.0128 & 0.3827 \\
\hline NEW ZEALAND & 1 & 278 & 0.1048 & 0.0533 & 0.0323 & 0.0158 & 0.3109 \\
\hline TURKEY & 1 & 277 & 0.1048 & 0.0532 & 0.0022 & 0.0134 & 0.3104 \\
\hline RUSSIA & 1 & 265 & 0.1238 & 0.0533 & 0.0006 & 0.0145 & 0.4392 \\
\hline SOUTH AFRICA & 1 & 229 & 0.1238 & 0.0533 & 0.0051 & 0.0153 & 0.4090 \\
\hline KOREA & 1 & 188 & 0.0667 & 0.0530 & 0.0000 & 0.0085 & 0.2585 \\
\hline SINGAPORE & 1 & 185 & 0.1048 & 0.0532 & 0.0049 & 0.0138 & 0.3286 \\
\hline MEXICO & 1 & 183 & 0.0762 & 0.0531 & 0.0015 & 0.0107 & 0.2263 \\
\hline PORTUGAL & 1 & 148 & 0.0857 & 0.0531 & 0.0004 & 0.0108 & 0.3134 \\
\hline GREECE & 1 & 148 & 0.0667 & 0.0530 & 0.0004 & 0.0089 & 0.2489 \\
\hline BRAZIL & 1 & 141 & 0.0667 & 0.0530 & 0.0017 & 0.0102 & 0.1877 \\
\hline POLAND & 1 & 128 & 0.0667 & 0.0530 & 0.0004 & 0.0090 & 0.2416 \\
\hline ESTONIA & 1 & 88 & 0.0381 & 0.0529 & 0.0000 & 0.0058 & 0.1629 \\
\hline INDIA & 1 & 69 & 0.0381 & 0.0529 & 0.0001 & 0.0060 & 0.1364 \\
\hline ARGENTINA & 1 & 69 & 0.0286 & 0.0528 & 0.0000 & 0.0050 & 0.1105 \\
\hline ICELAND & 1 & 52 & 0.0476 & 0.0531 & 0.0001 & 0.0069 & 0.2027 \\
\hline SLOVAKIA & 1 & 48 & 0.0571 & 0.0531 & 0.0001 & 0.0077 & 0.2330 \\
\hline CHILE & 1 & 45 & 0.0476 & 0.0529 & 0.0000 & 0.0070 & 0.1597 \\
\hline ROMANIA & 1 & 42 & 0.0286 & 0.0529 & 0.0000 & 0.0049 & 0.1320 \\
\hline CYPRUS & 1 & 37 & 0.0381 & 0.0528 & 0.0000 & 0.0060 & 0.1277 \\
\hline EGYPT & 1 & 33 & 0.0381 & 0.0528 & 0.0001 & 0.0057 & 0.1288 \\
\hline LITHUANIA & 1 & 33 & 0.0095 & 0.0526 & 0.0000 & 0.0028 & 0.0517 \\
\hline UKRAINE & 1 & 32 & 0.0190 & 0.0527 & 0.0000 & 0.0038 & 0.0936 \\
\hline VENEZUELA & 1 & 26 & 0.0286 & 0.0527 & 0.0000 & 0.0049 & 0.0943 \\
\hline COLOMBIA & 1 & 24 & 0.0286 & 0.0528 & 0.0000 & 0.0048 & 0.1297 \\
\hline LATVIA & 1 & 24 & 0.0286 & 0.0527 & 0.0000 & 0.0047 & 0.1083 \\
\hline PHILIPPINES & 1 & 16 & 0.0095 & 0.0510 & 0.0000 & 0.0029 & 0.0161 \\
\hline KYRGYZSTAN & 1 & 15 & 0.0476 & 0.0529 & 0.0000 & 0.0070 & 0.1597 \\
\hline ETHIOPIA & 1 & 13 & 0.0190 & 0.0527 & 0.0000 & 0.0041 & 0.0614 \\
\hline
\end{tabular}


Table 10 (continued)

\begin{tabular}{|c|c|c|c|c|c|c|c|}
\hline Node & Cluster & Degree & Norm degree & Closeness & Betweenness & PageRank & Authority \\
\hline$\overline{\text { ZIMBABWE }}$ & 1 & 12 & 0.0095 & 0.0526 & 0.0000 & 0.0028 & 0.0517 \\
\hline SRI LANKA & 1 & 11 & 0.0190 & 0.0528 & 0.0000 & 0.0039 & 0.0901 \\
\hline INDONESIA & 1 & 10 & 0.0286 & 0.0527 & 0.0012 & 0.0054 & 0.0721 \\
\hline BURK FASO & 1 & 6 & 0.0095 & 0.0517 & 0.0000 & 0.0027 & 0.0384 \\
\hline FIJI & 1 & 6 & 0.0095 & 0.0526 & 0.0000 & 0.0028 & 0.0517 \\
\hline GERMANY & 2 & 2093 & 0.3333 & 0.0540 & 0.0517 & 0.0405 & 0.8114 \\
\hline NETHERLANDS & 2 & 1515 & 0.2571 & 0.0538 & 0.0079 & 0.0287 & 0.7417 \\
\hline ITALY & 2 & 783 & 0.2571 & 0.0538 & 0.0098 & 0.0290 & 0.7101 \\
\hline SWITZERLAND & 2 & 762 & 0.2000 & 0.0536 & 0.0030 & 0.0225 & 0.6412 \\
\hline BELGIUM & 2 & 631 & 0.2190 & 0.0537 & 0.0175 & 0.0256 & 0.6446 \\
\hline FRANCE & 2 & 562 & 0.1714 & 0.0535 & 0.0191 & 0.0212 & 0.5444 \\
\hline SPAIN & 2 & 493 & 0.2095 & 0.0536 & 0.0101 & 0.0249 & 0.5995 \\
\hline AUSTRIA & 2 & 257 & 0.1429 & 0.0532 & 0.0013 & 0.0166 & 0.4568 \\
\hline HUNGARY & 2 & 204 & 0.1238 & 0.0534 & 0.0017 & 0.0149 & 0.4244 \\
\hline CZECH REP & 2 & 76 & 0.0476 & 0.0529 & 0.0000 & 0.0067 & 0.1890 \\
\hline SLOVENIA & 2 & 63 & 0.0190 & 0.0514 & 0.0001 & 0.0046 & 0.0361 \\
\hline LUXEMBOURG & 2 & 57 & 0.0571 & 0.0528 & 0.0000 & 0.0075 & 0.2324 \\
\hline NORWAY & 3 & 871 & 0.2286 & 0.0537 & 0.0221 & 0.0272 & 0.6570 \\
\hline SWEDEN & 3 & 778 & 0.1905 & 0.0536 & 0.0036 & 0.0217 & 0.5918 \\
\hline DENMARK & 3 & 692 & 0.1429 & 0.0534 & 0.0020 & 0.0168 & 0.4964 \\
\hline FINLAND & 3 & 300 & 0.1238 & 0.0532 & 0.0008 & 0.0145 & 0.4297 \\
\hline NIGERIA & 4 & 42 & 0.0000 & 0.0094 & 0.0000 & 0.0016 & 0.0000 \\
\hline MALTA & 5 & 31 & 0.0095 & 0.0517 & 0.0000 & 0.0027 & 0.0384 \\
\hline BULGARIA & 6 & 22 & 0.0381 & 0.0529 & 0.0000 & 0.0058 & 0.1464 \\
\hline GEORGIA & 7 & 17 & 0.0095 & 0.0526 & 0.0000 & 0.0028 & 0.0517 \\
\hline BOTSWANA & 8 & 16 & 0.0190 & 0.0521 & 0.0000 & 0.0037 & 0.0682 \\
\hline GHANA & 9 & 13 & 0.0095 & 0.0526 & 0.0000 & 0.0028 & 0.0517 \\
\hline UGANDA & 10 & 14 & 0.0190 & 0.0527 & 0.0000 & 0.0038 & 0.0856 \\
\hline KENYA & 11 & 12 & 0.0190 & 0.0527 & 0.0000 & 0.0038 & 0.0798 \\
\hline MOROCCO & 12 & 12 & 0.0000 & 0.0094 & 0.0000 & 0.0016 & 0.0000 \\
\hline THAILAND & 13 & 15 & 0.0286 & 0.0522 & 0.0003 & 0.0052 & 0.0678 \\
\hline LEBANON & 14 & 11 & 0.0095 & 0.0512 & 0.0000 & 0.0026 & 0.0281 \\
\hline SERBIA & 15 & 12 & 0.0190 & 0.0527 & 0.0027 & 0.0048 & 0.0535 \\
\hline BANGLADESH & 16 & 9 & 0.0286 & 0.0522 & 0.0000 & 0.0046 & 0.1031 \\
\hline MALAYSIA & 17 & 9 & 0.0095 & 0.0526 & 0.0000 & 0.0028 & 0.0517 \\
\hline IRAN & 18 & 6 & 0.0000 & 0.0094 & 0.0000 & 0.0016 & 0.0000 \\
\hline KAZAKHSTAN & 19 & 8 & 0.0190 & 0.0528 & 0.0000 & 0.0038 & 0.0988 \\
\hline MALAWI & 20 & 7 & 0.0095 & 0.0514 & 0.0000 & 0.0026 & 0.0339 \\
\hline U ARAB EMIR & 21 & 6 & 0.0000 & 0.0094 & 0.0000 & 0.0016 & 0.0000 \\
\hline COSTA RICA & 22 & 5 & 0.0095 & 0.0526 & 0.0000 & 0.0028 & 0.0517 \\
\hline CROATIA & 23 & 4 & 0.0000 & 0.0094 & 0.0000 & 0.0016 & 0.0000 \\
\hline KUWAIT & 24 & 4 & 0.0000 & 0.0094 & 0.0000 & 0.0016 & 0.0000 \\
\hline
\end{tabular}


Table 10 (continued)

\begin{tabular}{llrlllll}
\hline Node & Cluster & Degree & Norm degree & Closeness & Betweenness & PageRank & Authority \\
\hline OMAN & 25 & 6 & 0.0190 & 0.0527 & 0.0000 & 0.0038 & 0.0833 \\
PAKISTAN & 26 & 5 & 0.0095 & 0.0517 & 0.0000 & 0.0026 & 0.0419 \\
SENEGAL & 27 & 5 & 0.0095 & 0.0517 & 0.0000 & 0.0027 & 0.0384 \\
SUDAN & 28 & 6 & 0.0190 & 0.0527 & 0.0000 & 0.0038 & 0.0833 \\
URUGUAY & 29 & 7 & 0.0286 & 0.0528 & 0.0000 & 0.0048 & 0.1297 \\
UZBEKISTAN & 30 & 7 & 0.0286 & 0.0528 & 0.0000 & 0.0049 & 0.1113 \\
BELARUS & 31 & 3 & 0.0095 & 0.0517 & 0.0000 & 0.0027 & 0.0384 \\
BOLIVIA & 32 & 3 & 0.0095 & 0.0526 & 0.0000 & 0.0028 & 0.0517 \\
CAMBODIA & 33 & 2 & 0.0000 & 0.0094 & 0.0000 & 0.0016 & 0.0000 \\
CAMEROON & 34 & 2 & 0.0000 & 0.0094 & 0.0000 & 0.0016 & 0.0000 \\
ECUADOR & 35 & 3 & 0.0095 & 0.0517 & 0.0000 & 0.0027 & 0.0384 \\
GAMBIA & 36 & 2 & 0.0000 & 0.0094 & 0.0000 & 0.0016 & 0.0000 \\
GUATEMALA & 37 & 3 & 0.0095 & 0.0517 & 0.0000 & 0.0026 & 0.0419 \\
IRAQ & 38 & 3 & 0.0095 & 0.0526 & 0.0000 & 0.0028 & 0.0517 \\
JAMAICA & 39 & 2 & 0.0000 & 0.0094 & 0.0000 & 0.0016 & 0.0000 \\
LESOTHO & 40 & 2 & 0.0000 & 0.0094 & 0.0000 & 0.0016 & 0.0000 \\
LIBERIA & 41 & 2 & 0.0000 & 0.0094 & 0.0000 & 0.0016 & 0.0000 \\
MADAGASCAR & 42 & 2 & 0.0000 & 0.0094 & 0.0000 & 0.0016 & 0.0000 \\
MOLDOVA & 43 & 3 & 0.0095 & 0.0512 & 0.0000 & 0.0026 & 0.0272 \\
MONACO & 44 & 3 & 0.0095 & 0.0526 & 0.0000 & 0.0028 & 0.0517 \\
MONTENEGRO & 45 & 2 & 0.0000 & 0.0094 & 0.0000 & 0.0016 & 0.0000 \\
MOZAMBIQUE & 46 & 4 & 0.0190 & 0.0527 & 0.0000 & 0.0041 & 0.0614 \\
NEPAL & 47 & 2 & 0.0000 & 0.0094 & 0.0000 & 0.0016 & 0.0000 \\
NICARAGUA & 48 & 3 & 0.0095 & 0.0510 & 0.0000 & 0.0029 & 0.0161 \\
NIGER & 49 & 2 & 0.0000 & 0.0094 & 0.0000 & 0.0016 & 0.0000 \\
QATAR & 50 & 2 & 0.0000 & 0.0094 & 0.0000 & 0.0016 & 0.0000 \\
TANZANIA & 51 & 3 & 0.0095 & 0.0521 & 0.0000 & 0.0027 & 0.0471 \\
ZAMBIA & 52 & 3 & 0.0095 & 0.0521 & 0.0000 & 0.0027 & 0.0471 \\
\hline & & & & & & & \\
\hline
\end{tabular}


Table 11 Country collaboration network. Clustering and centrality of single countries within the network. All countries, 2010-2019

\begin{tabular}{|c|c|c|c|c|c|c|c|}
\hline Node & Cluster & Degree & Norm degree & Closeness & Betweenness & PageRank & Authority \\
\hline USA & 1 & 40,197 & 0.7969 & 0.4555 & 0.2835 & 0.0502 & 1.0000 \\
\hline UK & 1 & 20,072 & 0.7031 & 0.4369 & 0.1655 & 0.0388 & 0.9731 \\
\hline CANADA & 1 & 4570 & 0.4922 & 0.4000 & 0.0644 & 0.0256 & 0.8427 \\
\hline AUSTRALIA & 1 & 3357 & 0.4297 & 0.3902 & 0.0464 & 0.0217 & 0.7811 \\
\hline CHINA & 1 & 1688 & 0.3359 & 0.3765 & 0.0056 & 0.0153 & 0.7232 \\
\hline ISRAEL & 1 & 1599 & 0.2656 & 0.3668 & 0.0036 & 0.0123 & 0.6368 \\
\hline IRELAND & 1 & 1526 & 0.3906 & 0.3844 & 0.0137 & 0.0181 & 0.8078 \\
\hline TURKEY & 1 & 1053 & 0.2813 & 0.3678 & 0.0205 & 0.0141 & 0.6274 \\
\hline RUSSIA & 1 & 848 & 0.3203 & 0.3743 & 0.0043 & 0.0147 & 0.7043 \\
\hline KOREA & 1 & 847 & 0.1719 & 0.3526 & 0.0004 & 0.0084 & 0.4245 \\
\hline SOUTH AFRICA & 1 & 834 & 0.3047 & 0.3710 & 0.0196 & 0.0159 & 0.5559 \\
\hline JAPAN & 1 & 603 & 0.2109 & 0.3575 & 0.0025 & 0.0104 & 0.4520 \\
\hline SINGAPORE & 1 & 554 & 0.2734 & 0.3657 & 0.0062 & 0.0131 & 0.5700 \\
\hline NEW ZEALAND & 1 & 497 & 0.1953 & 0.3536 & 0.0019 & 0.0096 & 0.4370 \\
\hline MEXICO & 1 & 488 & 0.2188 & 0.3596 & 0.0015 & 0.0103 & 0.5242 \\
\hline BRAZIL & 1 & 483 & 0.2891 & 0.3699 & 0.0030 & 0.0132 & 0.6696 \\
\hline CHILE & 1 & 356 & 0.2578 & 0.3606 & 0.0020 & 0.0119 & 0.5994 \\
\hline INDIA & 1 & 317 & 0.2344 & 0.3606 & 0.0093 & 0.0121 & 0.4496 \\
\hline ARGENTINA & 1 & 217 & 0.1641 & 0.3488 & 0.0004 & 0.0079 & 0.4185 \\
\hline COLOMBIA & 1 & 204 & 0.1484 & 0.3478 & 0.0011 & 0.0076 & 0.3563 \\
\hline U ARAB EMIR & 1 & 186 & 0.1094 & 0.3413 & 0.0002 & 0.0059 & 0.2667 \\
\hline CYPRUS & 1 & 156 & 0.2266 & 0.3596 & 0.0002 & 0.0104 & 0.5720 \\
\hline ESTONIA & 1 & 154 & 0.1250 & 0.3450 & 0.0001 & 0.0064 & 0.3270 \\
\hline EGYPT & 1 & 122 & 0.0625 & 0.3316 & 0.0007 & 0.0045 & 0.1447 \\
\hline UKRAINE & 1 & 102 & 0.1641 & 0.3488 & 0.0000 & 0.0079 & 0.4291 \\
\hline KAZAKHSTAN & 1 & 100 & 0.0781 & 0.3377 & 0.0011 & 0.0049 & 0.1835 \\
\hline KENYA & 1 & 92 & 0.1016 & 0.3422 & 0.0006 & 0.0059 & 0.2345 \\
\hline CROATIA & 1 & 82 & 0.2109 & 0.3565 & 0.0008 & 0.0099 & 0.5049 \\
\hline MALAYSIA & 1 & 82 & 0.1016 & 0.3413 & 0.0008 & 0.0058 & 0.2238 \\
\hline NIGERIA & 1 & 82 & 0.0547 & 0.3290 & 0.0008 & 0.0040 & 0.1083 \\
\hline ICELAND & 1 & 81 & 0.0859 & 0.3368 & 0.0000 & 0.0048 & 0.2480 \\
\hline INDONESIA & 1 & 74 & 0.0703 & 0.3360 & 0.0000 & 0.0042 & 0.1926 \\
\hline THAILAND & 1 & 73 & 0.1250 & 0.3422 & 0.0008 & 0.0067 & 0.2787 \\
\hline PAKISTAN & 1 & 72 & 0.1016 & 0.3422 & 0.0013 & 0.0060 & 0.1953 \\
\hline SERBIA & 1 & 66 & 0.0938 & 0.3368 & 0.0038 & 0.0059 & 0.1898 \\
\hline PERU & 1 & 63 & 0.0547 & 0.3224 & 0.0001 & 0.0037 & 0.1062 \\
\hline LEBANON & 1 & 62 & 0.0625 & 0.3342 & 0.0000 & 0.0039 & 0.1842 \\
\hline TANZANIA & 1 & 51 & 0.0547 & 0.3307 & 0.0000 & 0.0038 & 0.1211 \\
\hline URUGUAY & 1 & 49 & 0.0469 & 0.3282 & 0.0000 & 0.0032 & 0.1254 \\
\hline GEORGIA & 1 & 48 & 0.0469 & 0.3274 & 0.0000 & 0.0033 & 0.1211 \\
\hline BANGLADESH & 1 & 47 & 0.1094 & 0.3351 & 0.0011 & 0.0063 & 0.1899 \\
\hline
\end{tabular}


Table 11 (continued)

\begin{tabular}{|c|c|c|c|c|c|c|c|}
\hline Node & Cluster & Degree & Norm degree & Closeness & Betweenness & PageRank & Authority \\
\hline GHANA & 1 & 47 & 0.0391 & 0.3299 & 0.0000 & 0.0029 & 0.1121 \\
\hline ECUADOR & 1 & 43 & 0.0469 & 0.3257 & 0.0000 & 0.0032 & 0.1357 \\
\hline SRI LANKA & 1 & 37 & 0.1250 & 0.3422 & 0.0020 & 0.0070 & 0.2294 \\
\hline UGANDA & 1 & 35 & 0.0625 & 0.3325 & 0.0028 & 0.0048 & 0.1098 \\
\hline PHILIPPINES & 1 & 35 & 0.0469 & 0.3224 & 0.0000 & 0.0032 & 0.1115 \\
\hline COSTA RICA & 1 & 33 & 0.0391 & 0.3290 & 0.0000 & 0.0029 & 0.1178 \\
\hline CAMBODIA & 1 & 28 & 0.0859 & 0.3377 & 0.0004 & 0.0050 & 0.2009 \\
\hline NEPAL & 1 & 28 & 0.1016 & 0.3333 & 0.0009 & 0.0059 & 0.1813 \\
\hline ZIMBABWE & 1 & 25 & 0.0391 & 0.3274 & 0.0000 & 0.0032 & 0.0821 \\
\hline AZERBAIJAN & 1 & 24 & 0.0156 & 0.3160 & 0.0000 & 0.0019 & 0.0459 \\
\hline SIERRA LEONE & 1 & 23 & 0.0469 & 0.3333 & 0.0000 & 0.0033 & 0.1346 \\
\hline BELARUS & 1 & 21 & 0.0469 & 0.3316 & 0.0000 & 0.0032 & 0.1375 \\
\hline RWANDA & 1 & 20 & 0.0547 & 0.3307 & 0.0003 & 0.0038 & 0.1095 \\
\hline VIETNAM & 1 & 19 & 0.0391 & 0.3325 & 0.0000 & 0.0030 & 0.1185 \\
\hline MALAWI & 1 & 19 & 0.0469 & 0.3290 & 0.0001 & 0.0037 & 0.0921 \\
\hline TUNISIA & 1 & 18 & 0.0313 & 0.3200 & 0.0000 & 0.0027 & 0.0782 \\
\hline IRAQ & 1 & 14 & 0.0391 & 0.3122 & 0.0000 & 0.0029 & 0.0843 \\
\hline SENEGAL & 1 & 11 & 0.0156 & 0.3241 & 0.0000 & 0.0020 & 0.0527 \\
\hline GUATEMALA & 1 & 11 & 0.0078 & 0.3145 & 0.0000 & 0.0016 & 0.0267 \\
\hline CONGO & 1 & 10 & 0.0156 & 0.3160 & 0.0000 & 0.0019 & 0.0461 \\
\hline JAMAICA & 1 & 9 & 0.0313 & 0.3282 & 0.0000 & 0.0026 & 0.0945 \\
\hline KUWAIT & 1 & 8 & 0.0078 & 0.3145 & 0.0000 & 0.0016 & 0.0267 \\
\hline GERMANY & 2 & 8193 & 0.5313 & 0.4063 & 0.0419 & 0.0255 & 0.9251 \\
\hline SWITZERLAND & 2 & 3336 & 0.3984 & 0.3855 & 0.0212 & 0.0191 & 0.7940 \\
\hline ITALY & 2 & 3252 & 0.4453 & 0.3926 & 0.0255 & 0.0212 & 0.8568 \\
\hline SPAIN & 2 & 2209 & 0.3906 & 0.3844 & 0.0140 & 0.0183 & 0.7779 \\
\hline FRANCE & 2 & 1854 & 0.4531 & 0.3938 & 0.0601 & 0.0237 & 0.8238 \\
\hline AUSTRIA & 2 & 1351 & 0.3281 & 0.3754 & 0.0031 & 0.0147 & 0.7588 \\
\hline PORTUGAL & 2 & 775 & 0.3125 & 0.3721 & 0.0198 & 0.0150 & 0.7160 \\
\hline HUNGARY & 2 & 672 & 0.3359 & 0.3765 & 0.0031 & 0.0149 & 0.7693 \\
\hline CZECH REP & 2 & 536 & 0.3203 & 0.3743 & 0.0094 & 0.0150 & 0.7164 \\
\hline POLAND & 2 & 509 & 0.3516 & 0.3787 & 0.0071 & 0.0159 & 0.7797 \\
\hline GREECE & 2 & 478 & 0.3281 & 0.3754 & 0.0030 & 0.0146 & 0.7591 \\
\hline ROMANIA & 2 & 230 & 0.2422 & 0.3606 & 0.0004 & 0.0110 & 0.6023 \\
\hline SLOVAKIA & 2 & 151 & 0.2891 & 0.3699 & 0.0010 & 0.0129 & 0.6988 \\
\hline SLOVENIA & 2 & 107 & 0.2266 & 0.3556 & 0.0024 & 0.0107 & 0.5161 \\
\hline LITHUANIA & 2 & 99 & 0.2500 & 0.3636 & 0.0007 & 0.0114 & 0.6086 \\
\hline BULGARIA & 2 & 93 & 0.1953 & 0.3516 & 0.0001 & 0.0091 & 0.4842 \\
\hline QATAR & 2 & 66 & 0.0313 & 0.3274 & 0.0000 & 0.0026 & 0.0982 \\
\hline LATVIA & 2 & 53 & 0.1875 & 0.3507 & 0.0000 & 0.0087 & 0.4728 \\
\hline VENEZUELA & 2 & 20 & 0.0469 & 0.3316 & 0.0000 & 0.0033 & 0.1256 \\
\hline JORDAN & 2 & 17 & 0.0234 & 0.3176 & 0.0000 & 0.0024 & 0.0553 \\
\hline
\end{tabular}


Table 11 (continued)

\begin{tabular}{|c|c|c|c|c|c|c|c|}
\hline Node & Cluster & Degree & Norm degree & Closeness & Betweenness & PageRank & Authority \\
\hline NETHERLANDS & 3 & 5196 & 0.4922 & 0.4000 & 0.0344 & 0.0238 & 0.8832 \\
\hline SWEDEN & 3 & 2964 & 0.3906 & 0.3844 & 0.0080 & 0.0177 & 0.8198 \\
\hline DENMARK & 3 & 2916 & 0.3672 & 0.3810 & 0.0129 & 0.0171 & 0.7737 \\
\hline BELGIUM & 3 & 2517 & 0.3750 & 0.3821 & 0.0146 & 0.0178 & 0.7678 \\
\hline NORWAY & 3 & 2339 & 0.3438 & 0.3776 & 0.0138 & 0.0165 & 0.7240 \\
\hline FINLAND & 3 & 976 & 0.3750 & 0.3821 & 0.0096 & 0.0171 & 0.7909 \\
\hline LUXEMBOURG & 3 & 145 & 0.1016 & 0.3432 & 0.0000 & 0.0055 & 0.2905 \\
\hline MALTA & 3 & 76 & 0.2188 & 0.3575 & 0.0001 & 0.0100 & 0.5538 \\
\hline MOZAMBIQUE & 3 & 22 & 0.0313 & 0.2922 & 0.0000 & 0.0025 & 0.0740 \\
\hline ARMENIA & 4 & 19 & 0.0234 & 0.2889 & 0.0000 & 0.0021 & 0.0626 \\
\hline ETHIOPIA & 5 & 19 & 0.0234 & 0.3216 & 0.0000 & 0.0023 & 0.0705 \\
\hline IRAN & 6 & 14 & 0.0156 & 0.3160 & 0.0000 & 0.0019 & 0.0503 \\
\hline BAHRAIN & 7 & 14 & 0.0156 & 0.3241 & 0.0000 & 0.0020 & 0.0527 \\
\hline MACEDONIA & 8 & 12 & 0.0156 & 0.3084 & 0.0000 & 0.0019 & 0.0489 \\
\hline SAUDI ARABIA & 9 & 15 & 0.0234 & 0.3114 & 0.0000 & 0.0022 & 0.0548 \\
\hline ALBANIA & 10 & 11 & 0.0078 & 0.2700 & 0.0000 & 0.0015 & 0.0168 \\
\hline KOSOVO & 11 & 14 & 0.0469 & 0.3114 & 0.0000 & 0.0034 & 0.0835 \\
\hline MOROCCO & 12 & 10 & 0.0156 & 0.3099 & 0.0000 & 0.0019 & 0.0480 \\
\hline AFGHANISTAN & 13 & 17 & 0.0703 & 0.3325 & 0.0006 & 0.0046 & 0.1107 \\
\hline CAMEROON & 14 & 11 & 0.0234 & 0.3122 & 0.0000 & 0.0022 & 0.0687 \\
\hline LAOS & 15 & 14 & 0.0469 & 0.3216 & 0.0000 & 0.0033 & 0.0877 \\
\hline SUDAN & 16 & 11 & 0.0234 & 0.3168 & 0.0000 & 0.0022 & 0.0705 \\
\hline UZBEKISTAN & 17 & 10 & 0.0313 & 0.3160 & 0.0000 & 0.0025 & 0.0846 \\
\hline LIBYA & 18 & 7 & 0.0078 & 0.3145 & 0.0000 & 0.0016 & 0.0267 \\
\hline MAURITIUS & 19 & 5 & 0.0078 & 0.3145 & 0.0000 & 0.0016 & 0.0267 \\
\hline MOLDOVA & 20 & 7 & 0.0078 & 0.2870 & 0.0000 & 0.0015 & 0.0225 \\
\hline ANGOLA & 21 & 5 & 0.0078 & 0.2723 & 0.0000 & 0.0015 & 0.0191 \\
\hline BHUTAN & 22 & 12 & 0.0625 & 0.3005 & 0.0001 & 0.0042 & 0.0796 \\
\hline BOLIVIA & 23 & 9 & 0.0391 & 0.3249 & 0.0001 & 0.0030 & 0.0844 \\
\hline BURK FASO & 24 & 5 & 0.0078 & 0.2838 & 0.0000 & 0.0015 & 0.0220 \\
\hline KYRGYZSTAN & 25 & 5 & 0.0078 & 0.3145 & 0.0000 & 0.0016 & 0.0267 \\
\hline MONTENEGRO & 26 & 6 & 0.0156 & 0.2864 & 0.0000 & 0.0019 & 0.0271 \\
\hline ZAMBIA & 27 & 6 & 0.0156 & 0.3084 & 0.0000 & 0.0018 & 0.0476 \\
\hline ALGERIA & 28 & 7 & 0.0391 & 0.3249 & 0.0000 & 0.0029 & 0.1176 \\
\hline BELIZE & 29 & 3 & 0.0078 & 0.3055 & 0.0000 & 0.0015 & 0.0260 \\
\hline BOTSWANA & 30 & 5 & 0.0234 & 0.3077 & 0.0000 & 0.0024 & 0.0438 \\
\hline CUBA & 31 & 16 & 0.1094 & 0.3122 & 0.0000 & 0.0055 & 0.2625 \\
\hline FIJI & 32 & 3 & 0.0078 & 0.2819 & 0.0000 & 0.0015 & 0.0209 \\
\hline MALI & 33 & 2 & 0.0000 & 0.0078 & 0.0000 & 0.0012 & 0.0000 \\
\hline MAURITANIA & 34 & 4 & 0.0156 & 0.2922 & 0.0000 & 0.0018 & 0.0432 \\
\hline NICARAGUA & 35 & 3 & 0.0078 & 0.3145 & 0.0000 & 0.0016 & 0.0267 \\
\hline OMAN & 36 & 3 & 0.0078 & 0.3145 & 0.0000 & 0.0016 & 0.0267 \\
\hline
\end{tabular}


Table 11 (continued)

\begin{tabular}{llrlllll}
\hline Node & Cluster & Degree & Norm degree & Closeness & Betweenness & PageRank & Authority \\
\hline SAN MARINO & 37 & 3 & 0.0078 & 0.2870 & 0.0000 & 0.0015 & 0.0225 \\
SOMALIA & 38 & 3 & 0.0078 & 0.3145 & 0.0000 & 0.0016 & 0.0267 \\
SWAZILAND & 39 & 4 & 0.0156 & 0.2838 & 0.0000 & 0.0020 & 0.0238 \\
SYRIA & 40 & 4 & 0.0156 & 0.2970 & 0.0000 & 0.0018 & 0.0483 \\
\hline
\end{tabular}

Acknowledgements I am grateful to Massimo Aria and the Bibliometrix Team for advice and suggestions on the use of the Bibliometrix R package. I would also like to thank the guest editors and anonymous reviewers for useful comments and suggestions.

Funding Open access funding provided by Università degli Studi di Catania within the CRUI-CARE Agreement.

Open Access This article is licensed under a Creative Commons Attribution 4.0 International License, which permits use, sharing, adaptation, distribution and reproduction in any medium or format, as long as you give appropriate credit to the original author(s) and the source, provide a link to the Creative Commons licence, and indicate if changes were made. The images or other third party material in this article are included in the article's Creative Commons licence, unless indicated otherwise in a credit line to the material. If material is not included in the article's Creative Commons licence and your intended use is not permitted by statutory regulation or exceeds the permitted use, you will need to obtain permission directly from the copyright holder. To view a copy of this licence, visit http://creativecommons.org/licen ses/by/4.0/.

\section{References}

Aria, Massimo, and Corrado Cuccurullo. 2017. Bibliometrix: An R-tool for comprehensive science mapping analysis. Journal of Informetrics 11 (4): 959-975. https://doi.org/10.1016/j.joi.2017.08.007.

Barabasi, Albert-laszlo. 2014. Linked: How everything is connected to everything else and what it means for business, science, and everyday life. New York: Basic Books.

Batagelj, Vladimir, and Monika Cerinšek. 2013. On bibliographic networks. Scientometrics 96 (3): $845-$ 864. https://doi.org/10.1007/s11192-012-0940-1.

Boydstun, Amber E., Shaun Bevan, and Herschel F. Thomas. 2014. The importance of attention diversity and how to measure it. Policy Studies Journal 42 (2): 173-196. https://doi.org/10.1111/psj.12055.

Closa, Carlos, Catherine Moury, Zuzana Novakova, Matt Qvortrup, and Beatriz Ribeiro. 2020. Mind the (submission) gap: EPSR gender data and female authors publishing perceptions. European Political Science 19 (3): 428-442. https://doi.org/10.1057/s41304-020-00250-5.

Fisher, Bonnie S., Craig T. Cobane, Thomas M. Ven Vander, and Francis T. Cullen. 1998. How many authors does it take to publish an article? Trends and patterns in political science. PS: Political Science \& Politics 31 (4): 847-56. https://doi.org/10.2307/420730.

Forrester, John P. 1996. Public administration productivity: An assessment of faculty in PA programs. Administration \& Society 27 (4): 537-566. https://doi.org/10.1177/009539979602700404.

Ghica, Luciana Alexandra. 2021. Who are we? the diversity puzzle in european political science. European Political Science 20 (1): 58-84. https://doi.org/10.1057/s41304-021-00319-9.

Grossman, Emiliano. 2020. A gender bias in the european journal of political research? European Political Science 19 (3): 416-427. https://doi.org/10.1057/s41304-020-00252-3.

Jensen, Mads Dagnis, and Peter Marcus Kristensen. 2013. The elephant in the room: Mapping the latent communication pattern in European Union studies. Journal of European Public Policy 20 (1): 1-20. https://doi.org/10.1080/13501763.2012.699656. 
Jensen, Magnus Rom, and Jonathon W. Moses. 2021. The state of political science, 2020. European Political Science 20 (1): 14-33. https://doi.org/10.1057/s41304-020-00297-4.

Jokić, Maja, Andrea Mervar, and Stjepan Mateljan. 2019. The development of political science in central and eastern Europe: bibliometric perspective, 1996. European Political Science 18 (3): 491-509. https://doi.org/10.1057/s41304-018-0191-6.

Keeler, John TS. 2005. Mapping EU studies: The evolution from boutique to boom field. JCMS: Journal of Common Market Studies 43 (3): 551-82. https://doi.org/10.1111/j.0021-9886.2005.00569.x.

Kristensen, Peter M. 2012. Dividing discipline: structures of communication in international relations. International Studies Review 14 (1): 32-50. https://doi.org/10.1111/j.1468-2486.2012.01101.x.

Leifeld, Philip, Sandra Wankmüller, Valentin T. Z. Berger, Karin Ingold, and Christiane Steiner. 2017. Collaboration patterns in the german political science co-authorship network. PLOS ONE 12 (4): e0174671. https://doi.org/10.1371/journal.pone.0174671.

Mas-Verdu, Francisco, Jose-Maria. Garcia-Alvarez-Coque, Paula Andrea Nieto-Aleman, and Norat RoigTierno. 2021. A systematic mapping review of European political science. European Political Science 20 (1): 85-104. https://doi.org/10.1057/s41304-021-00320-2.

Metz, Thomas, and Sebastian Jäckle. 2017. Patterns of publishing in political science journals: An overview of our profession using bibliographic data and a co-authorship network. PS: Political Science \& Politics 50 (1): 157-65. https://doi.org/10.1017/S1049096516002341.

Plümper, Thomas, and Claudio Radaelli. 2004. Publish or perish? Publications and citations of Italian political scientists in international political science journals, 1990-2002. Journal of European Public Policy 11 (6): 1112-1127. https://doi.org/10.1080/1350176042000298138.

Russett, Bruce, and Taylor Arnold. 2010. Who talks, and who's listening? Networks of international security studies. Security Dialogue 41 (6): 589-598. https://doi.org/10.1177/0967010610388205.

Wasserman, Stanley, and Katherine Faust. 1994. Social network analysis. Methods and applications. Cambridge: Cambridge University Press.

Williams, Helen, Stephen Bates, Laura Jenkins, Darcy Luke, and Kelly Rogers. 2015. Gender and journal authorship: an assessment of articles published by women in three top british political science and international relations journals. European Political Science 14 (2): 116-130. https://doi.org/10. 1057/eps.2015.8.

Publisher's Note Springer Nature remains neutral with regard to jurisdictional claims in published maps and institutional affiliations.

Marcello Carammia is a Senior Researcher at the University of Catania, Italy. Between 2015 and 2019, he was a Senior Researcher and Leader of the Research Team at the European Union Agency for Asylum. Previously, he was a Lecturer and then a Senior Lecturer at the University of Malta. His research interests include agenda setting processes, and migration processes, politics and policy. 